\title{
Structural Basis of Cerebellar Microcircuits in the Rat
}

\author{
Nadia L. Cerminara, ${ }^{1}$ Hanako Aoki, ${ }^{2}$ Michaela Loft, ${ }^{1}$ Izumi Sugihara, ${ }^{2 *}$ and Richard Apps ${ }^{1 *}$ \\ ${ }^{1}$ School of Physiology and Pharmacology, University of Bristol, Bristol BS8 1TD, United Kingdom, and ${ }^{2}$ Department of Systems Neurophysiology and \\ Center for Brain Integration Research, Tokyo Medical and Dental University, Tokyo 113-8519, Japan
}

The topography of the cerebellar cortex is described by at least three different maps, with the basic units of each map termed "microzones," "patches," and "bands." These are defined, respectively, by different patterns of climbing fiber input, mossy fiber input, and Purkinje cell (PC) phenotype. Based on embryological development, the "one-map" hypothesis proposes that the basic units of each map align in the adult animal and the aim of the present study was to test this possibility. In barbiturate anesthetized adult rats, nanoinjections of bidirectional tracer (Retrobeads and biotinylated dextran amine) were made into somatotopically identified regions within the hindlimb $\mathrm{C} 1$ zone in copula pyramidis. Injection sites were mapped relative to PC bands defined by the molecular marker zebrin II and were correlated with the pattern of retrograde cell labeling within the inferior olive and in the basilar pontine nuclei to determine connectivity of microzones and patches, respectively, and also with the distributions of biotinylated dextran amine-labeled PC terminals in the cerebellar nuclei. Zebrin bands were found to be related to both climbing fiber and mossy fiber inputs and also to cortical representation of different parts of the ipsilateral hindpaw, indicating a precise spatial organization within cerebellar microcircuitry. This precise connectivity extends to PC terminal fields in the cerebellar nuclei and olivonuclear projections. These findings strongly support the one-map hypothesis and suggest that, at the microcircuit level of resolution, the cerebellar cortex has a common plan of spatial organization for major inputs, outputs, and PC phenotype.

\section{Introduction}

Given the regular internal circuitry of the cerebellum, its role in motor control and other functions is thought to depend to a large extent on regional differences in afferent and efferent connectivity. In particular, climbing fibers (CFs) originate exclusively from the inferior olive and are topographically highly organized, with CFs arising from specific olivary subdivisions targeting Purkinje cells (PCs) in the contralateral cerebellar cortex arranged into longitudinally orientated "zones" that are $\sim 1-2 \mathrm{~mm}$ in mediolateral width. In turn, PCs located within each cortical zone provide a highly convergent projection to specific territories within the cerebellar and vestibular nuclei (Voogd et al., 1981; BuisseretDelmas and Angaut, 1993; Apps and Garwicz, 2005).

High-resolution electrophysiological mapping experiments have shown that some cortical zones can be further divided into smaller units termed “microzones." These are narrow $(0.1-0.3$

Received Feb. 25, 2013; revised June 21, 2013; accepted July 23, 2013.

Author contributions: N.L.C., I.S., and R.A. designed research; N.L.C., H.A., M.L., I.S., and R.A. performed research; N.L.C., H.A., M.L., I.S., and R.A. analyzed data; N.L.C., I.S., and R.A. wrote the paper.

This work was supported by the Medical Research Council, the Japan Society for the Promotion of Science (Grant-in-Aid for Scientific Research \#25430032), and the University of Bristol Institute for Advanced Studies (Benjamin Meaker Visiting Professorship to I.S.). We thank Ms. Rachel Bissett for technical assistance.

The authors declare no competing financial interests.

*I.S. and R.A. are co-senior authors.

This article is freely available online through the J Neurosci Author Open Choice option.

Correspondence should be addressed to Professor Izumi Sugihara, Dept. of Systems Neurophysiology, Tokyo Medical and Dental University Graduate School of Medicine, 1-5-45 Yushima, Bunkyo-ku, Tokyo 113-8519, Japan. E-mail: isugihara.phy1@tmd.ac.jp.

DOl:10.1523/JNEUROSCI.0861-13.2013

Copyright $\odot 2013$ Cerminara et al.

This is an Open Access article distributed under the terms of the Creative Commons Attribution License (http://creativecommons.org/licenses/by/3.0), which permits unrestricted use, distribution and reproduction in any medium provided that the original work is properly attributed. mm wide) longitudinal strips of cerebellar cortex located within each of the broader zones where $\mathrm{PC}$ s receive $\mathrm{CF}$-mediated input with similar receptive field identity (for review, see Garwicz et al., 1998). Microzones and their associated input-output connections are thought to represent the basic operational units of the cerebellum (Ruigrok, 2011). It is important therefore to understand cerebellar connectivity at this fundamental level of organization (Yeo and Hesslow, 1998; Apps and Garwicz, 2005; Ramnani, 2006).

In addition, micromapping of mossy fiber (MF) projections suggests that they form a "patchy" mosaic of receptive fields within the cerebellar cortex (the "fractured somatotopy" of Shambes et al., 1978). PCs are also organized into rostrocaudally oriented bands defined by the expression of molecular markers such as zebrin II (Brochu et al., 1990). Therefore, there appears to be several maps within the cerebellar cortex: CF microzones, MF patches, and PC phenotype bands. However, based on embryology, the "one-map" hypothesis postulates that these patterns of spatial organization reflect features of a unitary map: at a microcircuit level of resolution, a close correspondence exists between zebrin bands and MF and CF inputs (Apps and Hawkes, 2009). During embryogenesis, migration of PC clusters occurs in the rostrocaudal axis, forming a series of longitudinally oriented bands defined by the restricted expression of molecular markers (Fujita et al., 2012; Sugihara and Fujita, 2013). The hypothesis proposes that MF and CF afferents then use the PC clusters as a "scaffold" to organize their own topography (Apps and Hawkes, 2009).

The aim of the present investigation was to study the fine grain anatomical relationships between cerebellar cortical connectivity and zebrin immunocytochemistry to test the one-map hypothesis. The results in the rat focus on microcircuit connections of the $\mathrm{C} 1$ zone in the copula pyramidis (CP) because the general anat- 
omy and physiology of this region has been described previously (Atkins and Apps, 1997) and because of its likely importance in limb movement (Pijpers et al., 2008). Here, we show that at the microcircuit level, cerebellar cortical inputs and outputs are closely related to zebrin bands. Such findings provide strong support for the one-map hypothesis and extend the concept to PC outputs.

\section{Materials and Methods}

Animals. Results were obtained from a total of 29 male and female adult Wistar or Long-Evans rats (250-300 g). Nineteen experiments were conducted at the School of Physiology and Pharmacology, University of Bristol, in accordance with the UK Animals (Scientific Procedures) Act of 1986 and were approved by the institutional ethical review group. Ten experiments were conducted at the Department of Systems Neurophysiology, Tokyo Medical and Dental University, in accordance with the guiding principles for the care and use of animals in the field of physiological sciences of the Japanese Physiological Society $(2001,2002)$. Experimental procedures were approved by the institutional animal care and use committee of Tokyo Medical and Dental University.

Surgical procedures. In brief, rats were anesthetized with sodium pentobarbitone (60-70 mg/kg i.p.; Sigma-Aldrich) and supplemental doses were given as required to maintain surgical levels of anesthesia, determined by regular testing of leg withdrawal and corneal reflexes. The rats were secured in a stereotaxic frame and body temperature was maintained within physiological limits using a heated blanket controlled by a probe measuring rectal temperature. A small craniotomy exposed part of the posterior lobe of the cerebellum on one side, allowing access to the $\mathrm{CP}$. The dura was removed and the cerebellar cortex was periodically flushed with sterile saline.

Electrophysiological stimulation and recording. In experiments in which electrophysiological mapping of the $\mathrm{C} 1$ zone in $\mathrm{CP}$ was performed $(n=$ 18), the mediolateral sequence of cerebellar field potentials evoked by ipsilateral hindlimb and tail stimulation was mapped at individual recording sites, as described previously (Atkins and Apps, 1997). In brief, percutaneous electrical stimulation was applied (single pulse or double 1 $\mathrm{kHz}$ pulse; $0.1 \mathrm{~ms}$ duration square wave pulse) once every $2 \mathrm{~s}$ at an intensity sufficient to evoke a small but visible twitch in the body part stimulated. The evoked field potentials were recorded extracellularly from the surface of CP using custom-made tungsten-in-glass microelectrodes (tip diameter $\sim 50 \mu \mathrm{m}$, impedance $\sim 500 \mathrm{k} \Omega$ ). In four experiments, percutaneous stimulation involved the whole ipsilateral hindlimb or tail and, in the remainder $(n=14)$, percutaneous stimulation was refined to electrical stimulation of two or more different sites on the ipsilateral hindpaw (see Results for further details). This allowed activation of skin areas corresponding to receptive fields represented within the broader $\mathrm{C} 1$ zone. Consistent with previous studies, different physiologically identified cortical regions were defined by the peripheral stimulation site that evoked the largest response within that mediolateral part of the whole zone (Garwicz et al., 1996; Atkins and Apps, 1997).

The mediolateral distance between successive recording loci was $0.1-$ $0.2 \mathrm{~mm}$ and a sequence of typically $6-10$ recording positions was charted in $\mathrm{CP}$ in each experiment. The total number of sites recorded in each animal was limited by time constraints associated with recovery experiments, so it was not possible to record the complete mediolateral sequence of responses present within the $\mathrm{C} 1$ zone in every experiment. Instead, the overall distribution of cerebellar responses was derived by combining data from all physiological mapping experiments.

Evoked cerebellar cortical responses were recorded differentially, amplified, and band-pass filtered $(30-5 \mathrm{kHz})$ and any $50-60 \mathrm{~Hz}$ electrical interference was removed (without signal degradation) using a Humbug device (Quest Scientific). Responses were digitized online (sampling rate $10 \mathrm{kHz}$ ) using a Cambridge Electronic Design 1401plus A/D converter and customized trigger-sampled software (Spike2; Cambridge Electronic Design). Responses evoked at each recording site were averaged online $(n=10)$ to determine the somatotopical input to different parts of the $\mathrm{C} 1$ zone in CP and to guide placement of injections of tracer (see below).

Anatomical tracing. Red and green fluorescently tagged beads (Retrobeads; Lumafluor) were used as retrograde tracers and biotinylated dextran amine (BDA, D-1956, 10,000 MW or D-7135, 3000 MW; 10\% solution in saline; Invitrogen) was used for anterograde labeling. After the electrophysiological mapping stage of the experiment (see above), Retrobeads $(4-30 \mathrm{nl}$ ) were pressure injected from a micropipette (tip diameter $\sim 20 \mu \mathrm{m}$ ) with a Picopump PV820 (WPI) into the cerebellar cortex, generating a small but clearly visible deposit of fluorescent tracer material just below the cortical surface (Fig. $1 D, E$ ). The anterograde tracer was injected using the same parameters as the Retrobeads. In most cases, the injection site of Retrobeads and/or BDA was immediately subjacent to the location on the surface where the largest cerebellar responses were evoked by peripheral stimulation of a particular body part- that is, each injection was usually made into approximately the center of a specific somatotopically defined cortical region within the $\mathrm{C} 1$ zone (hereafter termed "region"). Seven animals received a single Retrobeads injection, and nine animals received an injection of red Retrobeads into one cortical region and an injection of green Retrobeads into another, thereby generating a total of 25 Retrobead cases (for details, see Tables 1,2). In the majority of these cases, BDA was also injected into the cortical location marked by a visible spot of Retrobeads (termed a paired injection site, $n=14$; Fig. $1 D-F)$. In the 14 animals that received paired Retrobead and BDA tracer injections, six animals received one or more additional injections of BDA into an additional cortical region. A further eight animals received either a single or two separate injections solely of $\mathrm{BDA}$, thereby generating a total of $29 \mathrm{BDA}$ cases. Five of these experiments used cerebellar surface anatomical landmarks to guide the placement of injections into the cerebellar cortex. All injection sites were made at a depth of approximately $0.2-0.3 \mathrm{~mm}$ perpendicular to the pial surface of the cerebellum.

In another set of five experiments, red and/or green Retrobeads were injected into the cerebellar nuclei while the animal's head was angled nose down 40-45 degrees using the central apex of lobule VIc (1.7-2.2 $\mathrm{mm}$ lateral to the midline, $3.3 \mathrm{~mm}$ deep; Paxinos and Watson, 2007) to guide the placement of the injection micropipette.

In all experiments, the micropipette was immediately withdrawn after injection of tracer, the surface of the cerebellum was rinsed with saline, and the exposed cortex was covered with Gelfoam (Sterispon, Allen and Hanbury). The overlying muscle and skin were closed in layers and the animal was allowed to recover. Upon recovery, a long-acting analgesic was given (Temgesic, $0.1 \mathrm{mg} / \mathrm{kg}$ i.m.; Reckitt and Colman). All animals were monitored daily and recovered uneventfully.

Histology. After a survival period of 7-10 d to allow axonal transport of tracers to occur, each animal was administered a lethal dose of sodium pentobarbitone $(180-200 \mathrm{mg} / \mathrm{kg}$ i.p.), and perfused transcardially with $500 \mathrm{ml}$ of heparinized $0.9 \%$ saline rinse followed by $500 \mathrm{ml}$ of $4 \%$ or $5 \%$ paraformaldehyde fixative and then $500 \mathrm{ml}$ of $0.2 \mathrm{M}$ or $50 \mathrm{~mm}$ phosphate buffer ( $\mathrm{pH} 7.4$ ) containing 10\% sucrose. Subsequently, the brainstem and cerebellum were removed and allowed to sink in 30\% sucrose stored at $4^{\circ} \mathrm{C}$. The cerebellum and brainstem were separated into two blocks of tissue and the cerebellum was embedded in gelatin. A freezing microtome was used to cut the cerebellum and brainstem into 80 and $50 \mu \mathrm{m}$ transverse sections, respectively. Cerebellar sections were mounted serially after immunostaining (see below) and brainstem sections were mounted as two separate series: one for analysis and the other as a spare.

For cerebellar sections, the immunohistological procedures used to double label BDA (black reaction product) and zebrin (brown reaction product) with diaminobenzidine have been described previously (Sugihara and Shinoda, 2004). In brief, BDA was visualized with an Elite ABC kit (PK6100; Vector Laboratories). The zebrin antibody used in this study was raised in Tokyo by immunizing a rabbit with a synthetic peptide that represented amino acids 322-344 from rat aldolase C (Sugihara and Shinoda, 2004). The cerebellar lobules were defined according to Larsell (1952) and Voogd (2004) and zebrin-immunopositive and zebrin-negative bands were defined according to Sugihara and Shinoda (2004). The nomenclature used for each zebrin band was indicated by a numeral and/or a letter plus either a negative or positive sign (Fig. $1 A, B$ ).

Anatomical mapping. BDA material was viewed with an Olympus BX50 microscope. For mapping of fluorescent labeling, sections were inspected with a Zeiss Axioskop II or Olympus BX51W1 microscope fitted with a $100 \mathrm{~W}$ mercury UV light source. For the Zeiss microscope, 


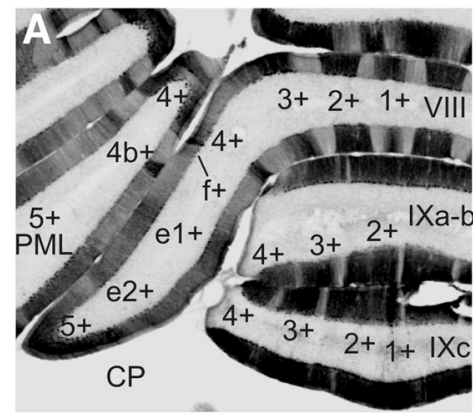

B
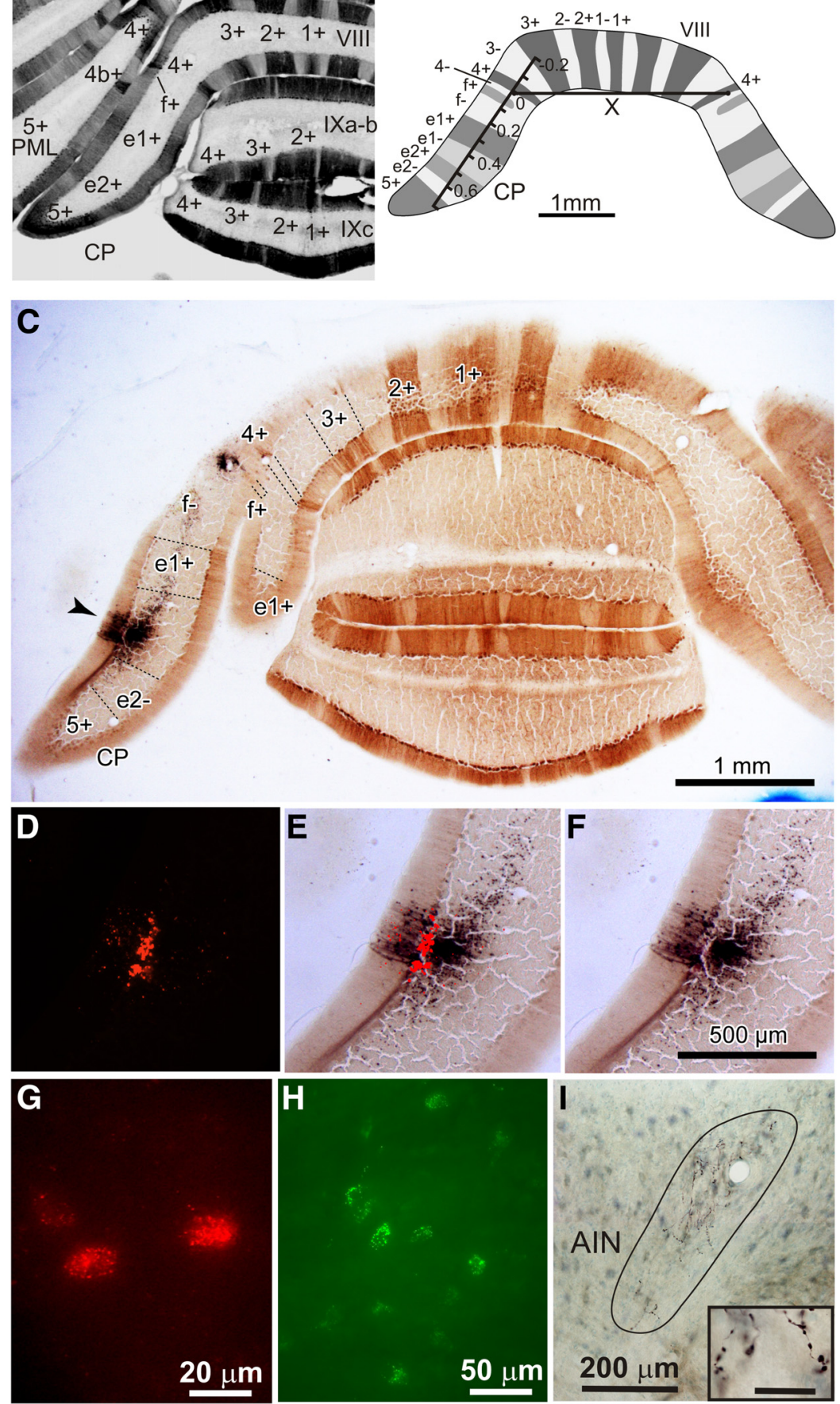

Figure 1. Photomicrographs of injection sites, labeling, and schematic of zebrin bands. A, Photomicrograph of a coronal section of the rat posterior cerebellum labeled for zebrin together with identification of individual zebrin-positive bands. Zebrin was visualized with diaminobenzidine. PML, paramedian lobule; VIII, vermal lobule 8; IXa-b, vermal lobule 9a-b; IXc, vermal lobule 9 c. $\boldsymbol{B}$, Schematic showing the method used to normalize location of tracer injection sites in CP. A laterality index was determined by measuring the distance from the injection site center to the ipsilateral zebrin band $4+$. This value was divided by the length $(X)$ between the centers of the lateral boundary of zebrin band $4+$ on the left and right sides of the brain. $C$, Low-power photomicrograph of coronal section of rat cerebellum labeled for zebrin and showing an example injection site of BDA (arrowhead). $\boldsymbol{D}$, High-power photomicrograph of $\boldsymbol{C}$ showing the red Retrobeads injection site. $\boldsymbol{E}$, High-power photomicrograph of $\boldsymbol{C}$ showing overlay between BDA and red Retrobeads injection site. $\boldsymbol{F}$, High-power photomicrograph of $\boldsymbol{C}$ showing BDA site. Scale bar in $\boldsymbol{F}$ also applies to photomicrographs $\boldsymbol{D}$ and $\boldsymbol{E}$. $\boldsymbol{G}$, High-power photomicrograph of olive cells retrogradely labeled with red Retrobeads. $\boldsymbol{H}$, High-power photomicrograph of pontine cells retrogradely labeled with green Retrobeads. I, High-power photomicrograph showing area occupied by anterogradely labeled PC axon preterminals/terminals in AIN (enclosed by line). Inset: Labeled PC axon terminals in AIN. Scale bar for inset, $20 \mu \mathrm{m}$. red fluorescent labeling was viewed using filter set number 15 (DM 580 nm, BP 546/12 nm, LP $590 \mathrm{~nm}$ ) and green fluorescence was viewed using filter set number 09 (DM $510 \mathrm{~nm}, \mathrm{BP}$ 450-490 nm, LP $515 \mathrm{~nm}$ ). For the Olympus microscope, the combinations of the fluorescent tracer, emission filter, dichroic mirror, and emission filter were 455-495 nm (XF1073), $500 \mathrm{~nm}$ (XF2010), 498-522 nm (XF3080) for green fluorescence, and 502-548 nm (XF1074), $560 \mathrm{~nm}$ (XF2017), 565-595 nm (XF3022; all filters were from Omega Optical) for red fluorescence. No difference was found in the pattern or extent of labeling using the two different microscopes. In 25 cases, all retrogradely labeled cells in the inferior olive (Fig. $1 G$ ) in one series of sections were counted and represented on standard transverse maps (Apps, 1990). For ease of comparison and to aid illustration of any topographical differences, the standard olivary maps were then converted to those in the horizontal plane (Fig. 3). In 10 cases, all retrogradely labeled cells in the basilar pontine nuclei (BPN; Fig. 1H) in one series of sections were also mapped. Standard transverse maps of the BPN were used to aid visualization of any topographical differences (Herrero et al., 2002).

The distribution of PC terminals in the cerebellar nuclei for 29 cases was first mapped on a 3D template of the adult rat cerebellar nuclei and dorsal part of the vestibular nuclei using 3D graphic software (Rhinoceros 4; Robert McNeel and Associates) as described previously (Sugihara and Shinoda, 2007). To show the distribution in illustrations, the terminal field was superimposed on a horizontal projection of the whole cerebellar nuclei and the terminal field viewed in the frontal plane was also superimposed on a drawing of the coronal section at the level nearest to the center of the distribution area. Terminal fields were defined as those territories within the cerebellar nuclei in which labeling was present in fine preterminal axons and their varicosities (Fig. 1I) or, for areas of nuclei containing dense labeling (where it was difficult to distinguish preterminals), as the area occupied by a plexus of both finely labeled and more coarsely labeled fibers.

Quantitative analysis of the distribution of cells in the inferior olive and terminal labeling in the cerebellar nuclei was also performed by determining the area within these territories that had the highest density of labeling. Starting at the lateral edge in the standard transverse section plots, the dorsal accessory olive (DAO) was divided into $0.2 \mathrm{~mm}$ wide bins and the number of cells in each bin was counted at each $0.2 \mathrm{~mm}$ rostrocaudal level (Garwicz et al., 1996). Retrobead injection site cases that were restricted or centered on a single zebrin band were then pooled and the average number of cells per bin was calculated in both the mediolateral and rostrocaudal dimensions. The bin(s) that contained the largest average number of cells was deemed the area of highest cell density for cases associated with each zebrin band (Fig. 3H).

A similar method was used to determine where the greatest overlap of terminal labeling 
Table 1. Characteristics of paired injections in cortex of CP

\begin{tabular}{|c|c|c|c|c|c|c|}
\hline $\begin{array}{l}\text { Paired } \\
\text { injection }\end{array}$ & Tracer & Physiology & $\begin{array}{l}\text { Volume } \\
\text { (nl) }\end{array}$ & $\begin{array}{l}\text { Injection } \\
\text { site diameter } \\
(\mu \mathrm{M})\end{array}$ & $\begin{array}{l}\text { Zebrin } \\
\text { band }\end{array}$ & $\begin{array}{l}\text { Laterality } \\
\text { index }\end{array}$ \\
\hline $7 G B$ & $\mathrm{~GB}$ & Hindlimb & 15 & 168 & $f-$ & 0.1 \\
\hline 7GB-BDA & BDA & & 0.5 & 150 & $f-$ & 0.13 \\
\hline $11 R B$ & $\mathrm{RB}$ & Hindlimb & 15 & 184 & $f-$ & 0.09 \\
\hline 11RB-BDA & BDA & & 0.5 & 184 & e1+ & 0.31 \\
\hline $12 \mathrm{~GB}$ & $\mathrm{~GB}$ & Medial & 15 & 56 & e1+ & 0.40 \\
\hline 12GB-BDA & BDA & & 0.5 & 192 & e1+ & 0.34 \\
\hline $14 G B$ & $G B$ & Lateral & 15 & 157 & $\mathrm{e} 2+>\mathrm{e} 2-$ & 0.58 \\
\hline 14GB-BDA1 & BDA & & 0.5 & 150 & $\mathrm{e} 2+$ & 0.58 \\
\hline $16 \mathrm{RB}$ & $\mathrm{RB}$ & Lateral & 15 & 96 & $\mathrm{e} 2->\mathrm{e} 2+$ & 0.6 \\
\hline 16RB-BDA & BDA & & 0.5 & 120 & $\mathrm{e} 2+$ & 0.58 \\
\hline $17 R B$ & $\mathrm{RB}$ & Medial & 15 & 69 & e1- & 0.43 \\
\hline 17RB-BDA & BDA & & 0.5 & 85 & e1- & 0.43 \\
\hline $18 \mathrm{~GB}$ & GB & Medial & 5 & 115 & e1- & 0.45 \\
\hline 18GB-BDA & BDA & & 0.5 & 38 & e1- & 0.46 \\
\hline $20 G B$ & $G B$ & Medial & 15 & 87 & e1- & 0.43 \\
\hline 20GB-BDA & BDA & & 0.5 & 105 & e1- & 0.43 \\
\hline $21 R B$ & $\mathrm{RB}$ & Heel & 15 & 92 & $f-$ & 0.08 \\
\hline 21RB-BDA & BDA & & 0.5 & 85 & $f-(e 1+)$ & 0.17 \\
\hline $22 G B$ & $G B$ & Heel & $?$ & 54 & $f-$ & 0.16 \\
\hline 22GB-BDA & BDA & & 0.5 & 108 & $f-$ & 0.16 \\
\hline $23 R B$ & $\mathrm{RB}$ & Heel & 15 & 490 & e1+ & 0.30 \\
\hline 23RB-BDA & BDA & & 0.5 & 38 & e1+ & 0.32 \\
\hline $23 G B$ & $G B$ & Lateral & 15 & 131 & e1 - & 0.46 \\
\hline 23GB-BDA & BDA & & 0.5 & 85 & $e 2+(e 1-)$ & 0.48 \\
\hline $24 R B$ & $\mathrm{RB}$ & Heel & 30 & 154 & e1- & D \\
\hline 24RB-BDA & BDA & & 0.5 & 200 & e1+ & $D$ \\
\hline $25 \mathrm{RB}$ & $\mathrm{RB}$ & Lateral & 15 & 62 & e2+ & 0.54 \\
\hline 25RB-BDA & BDA & & 0.5 & 115 & $\mathrm{e} 2+$ & 0.54 \\
\hline
\end{tabular}

Characteristics of paired injections into cerebellar cortex of CP. Paired injections involved a Retrobeads and a BDA injection at approximately the same cortical location. Physiology refers to the stimulated part of the ipsilateral hindlimb or hindpaw that evoked the largest responses on the cerebellar surface where the paired injection was made. Zebrin band in brackets indicate injection sites that have a small amount of spread to that zebrin band. For injection sites that spanned two zebrin bands, ${ }^{\prime}>$ " indicates in which zebrin band the injection site is predominantly located. Laterality index is a normalized measurement of injection site location relative to zebrin band $4+$ (see Materials and Methods). " $D$ " indicates that the laterality index could not be calculated because the section at the core location of the injection site was damaged. GB, green Retrobeads; RB, red Retrobeads.

in the cerebellar nuclei occurred. The horizontal projection of the whole cerebellar nuclei on one side of the brain was divided into $0.2 \mathrm{~mm} \times 0.2$ $\mathrm{mm}$ squares and, for each case, the square(s) that contributed the most terminal label was noted. A composite of terminal labeling was then created for BDA injections restricted or centered on a single zebrin band to determine which square(s) dominated the group (i.e., the aim was to determine the square(s) that dominated the terminal fields for the different zebrin bands; Fig. 5).

Injection sites were photographed (bright field for BDA, fluorescence plus bright field for red and green Retrobeads) and mapped on a template of the $\mathrm{CP}$ with zebrin-banding patterns (Fig. 1C). Where Retrobeads and BDA tracer were injected at the same cortical location (paired injection sites), the extent of overlap between the two injection sites was estimated by first measuring the distance of the center of each injection site from zebrin band $4+$ (see below) and the mediolateral width of the two injection sites and then determining the percentage overlap of each injection site.

Zebrin banding. In CP (and vermal lobule VIII, which is continuous with $\mathrm{CP}$ ) zebrin-positive bands $1+, 2+, 3+, 4+, \mathrm{f}+, \mathrm{e} 1+, \mathrm{e} 2+$, and $5+$ are present from the midline to the lateral pole (Sugihara and Shinoda, 2004, their Fig. 1A). Medial positive bands $(1+, 2+, 3+$, and $4+)$ are intensely labeled stripes and are clearly recognized in all brains. However, lateral zebrin-positive bands ( $\mathrm{f}+, \mathrm{e} 1+, \mathrm{e} 2+$, and $5+$ ) are sometimes less clearly distinguished from intercalating negative bands. This was particularly so in brains in which tracers were injected in this part of CP, presumably due to local tissue damage by the injection pipette and staining protocols for BDA tracer. Therefore, we measured the distance between the injection site center of the lateral boundary of ipsilateral zebrin
Table 2. Characteristics of single injections in cortex of CP

\begin{tabular}{|c|c|c|c|c|c|c|}
\hline Case & Tracer & Physiology & $\begin{array}{l}\text { Volume } \\
(\mathrm{nl})\end{array}$ & $\begin{array}{l}\text { Injection } \\
\text { site diameter } \\
(\mu \mathrm{M})\end{array}$ & $\begin{array}{l}\text { Zebrin } \\
\text { band }\end{array}$ & $\begin{array}{l}\text { Laterality } \\
\text { index }\end{array}$ \\
\hline $5 B D A$ & BDA & Hindlimb & 0.5 & 69 & e1+ & 0.39 \\
\hline $12 \mathrm{RB}$ & $\mathrm{RB}$ & Lateral & 15 & 202 & $\mathrm{e} 1->\mathrm{e} 2+$ & 0.48 \\
\hline 14RB & $\mathrm{RB}$ & Medial & 0.5 & 80 & e1- & 0.44 \\
\hline 14GB-BDA2 & BDA & Not tested & 0.5 & 150 & e2- & 0.63 \\
\hline $15 B D A$ & BDA & Hindlimb & 0.5 & 100 & $f+$ & 0.07 \\
\hline 16BDA & BDA & Mixed & 0.5 & 144 & e1+ & 0.32 \\
\hline 18RB-BDA & BDA & Lateral & $?$ & 31 & $f+$ & 0.08 \\
\hline 19BDAa & BDA & Not tested & 0.5 & 150 & $4-$ & 0.04 \\
\hline 19BDAb & BDA & Not tested & $?$ & 17 & e1+ & 0.51 \\
\hline $20 R B$ & $\mathrm{RB}$ & Lateral & 15 & 95 & $\mathrm{e} 2->\mathrm{e} 2+$ & 0.58 \\
\hline 20GB-BDA2 & BDA & Not tested & $?$ & 45 & $\mathrm{e} 2+$ & 0.47 \\
\hline 23-BDA & BDA & Lateral & 0.5 & 108 & $4-$ & 0.01 \\
\hline $24 G B$ & GB & Center & 30 & 123 & e1+ & 0.26 \\
\hline $25 G B$ & $G B$ & Heel & 15 & 154 & $f-$ & 0.19 \\
\hline $25 \mathrm{BDA}$ & BDA & Tail & 0.5 & 54 & $f+$ & 0.05 \\
\hline $31 R B$ & $\mathrm{RB}$ & Medial & 5 & 223 & $\mathrm{e} 1-\& \mathrm{e} 2+$ & 0.48 \\
\hline $31 G B$ & $G B$ & Lateral & 5 & 149 & $\mathrm{e} 2+>\mathrm{e} 2-$ & 0.67 \\
\hline $32 \mathrm{RB}$ & $\mathrm{RB}$ & Medial & 10 & 138 & $\mathrm{e} 1+(\mathrm{e} 1-)$ & 0.43 \\
\hline $32 G B$ & $\mathrm{~GB}$ & Lateral & 30 & 302 & $e 1+(f-)$ & 0.36 \\
\hline $36 \mathrm{RB}$ & $\mathrm{RB}$ & Medial & 15 & 64 & $\mathrm{e} 1+$ & 0.22 \\
\hline $36 \mathrm{~GB}$ & $G B$ & Lateral & 15 & 133 & e2+ & 0.57 \\
\hline 559rtCop1 & BDA & Not tested & 2 & 50 & $4+$ & -0.01 \\
\hline 567rtCop & BDA & Not tested & 2 & 55 & e2- & 0.61 \\
\hline 520ltCop & BDA & Not tested & 2 & 110 & e2- & 0.61 \\
\hline 571rtCop & BDA & Not tested & 2 & 140 & e2+ & 0.48 \\
\hline 559rtCop2 & BDA & Not tested & 2 & 120 & $\mathrm{e} 2+$ & 0.46 \\
\hline
\end{tabular}

Characteristics of single injections into cerebellar cortex of CP. Same conventions as Table 1 except " $\&$ " denotes an injection site that was distributed evenly across two zebrin bands. GB, green Retrobeads; RB, red Retrobeads.

band $4+$. To normalize the distances of injection sites in different animals, this value was divided by the distance between the lateral boundary of band $4+$ on the left and right hand sides of the cerebellum (Fig. 1B, "X") to determine a "laterality index." The laterality index of the zebrin bands were as follows: $3-,-0.17$ to $-0.05 ; 4+,-0.05$ to $0 ; 4-, 0$ to 0.04 ; $\mathrm{f}+, 0.04$ to 0.08 ; $\mathrm{f}-, 0.08$ to 0.22 ; e1,+ 0.22 to 0.38 ; e1-, 0.38 to 0.48 ; e2,+ 0.48 to 0.58 ; e2,- 0.58 to 0.66 ; and $5+,>0.66$. Very occasionally, the calculated laterality index of the injection site (e.g., case 12GB) did not fall within the normalized zebrin band range, most probably because of some interanimal variation.

Photomicrographs were taken by using a digital camera (DP-70; Olympus) and photographs assembled using Adobe Photoshop and Illustrator software. The software was used to adjust contrast and brightness, but no other digital enhancements were applied.

\section{Results}

Somatotopical organization of the hindlimb C1 zone in CP

As a first step, we used electrophysiological recording methods to map the approximate physiological boundaries of the $\mathrm{C} 1$ zone on the dorsal surface of CP. Initial experiments used percutaneous electrical stimulation of the ipsilateral hindlimb and tail at an intensity sufficient to evoke a small but visible twitch in the stimulated body part. In agreement with previous studies (Atkins and Apps, 1997), field potentials were evoked by tail stimulation in medial CP (onset latency of $18.3 \pm 0.2 \mathrm{~ms}$, mean $\pm \mathrm{SD} ; n=2$ ), whereas more laterally, field potentials were evoked by ipsilateral hindlimb stimulation (onset latency of $17.8 \pm 3.6 \mathrm{~ms}, n=4$ ). In 14 rats, we examined the finer grain somatotopical organization within the hindlimb-receiving part of the $\mathrm{C} 1$ zone by stimulating different parts of the ipsilateral hindpaw. Figure 2 shows sample data from a representative experiment. A dorsal view of the posterior lobe of the rat cerebellum shows the distribution of responses evoked from medial to lateral across the $\mathrm{C} 1$ zone in $\mathrm{CP}$ 
A

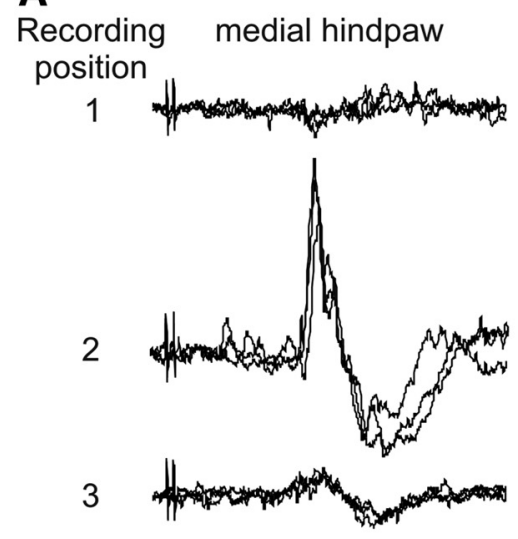

4

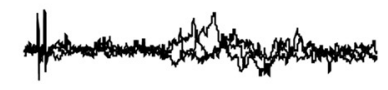

5

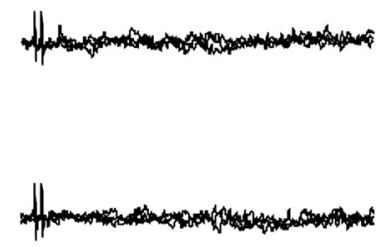

6

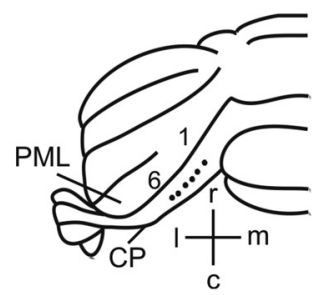

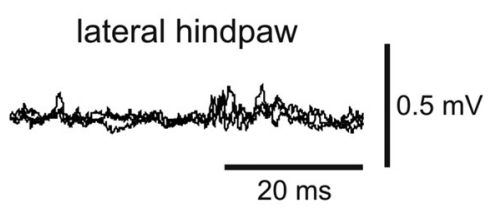
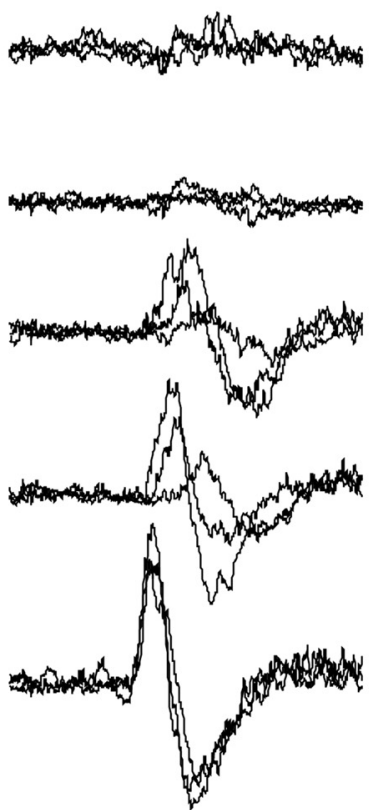

B

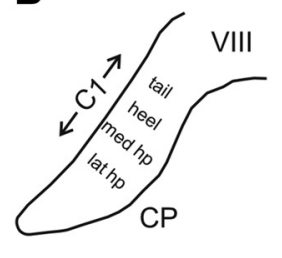

Figure 2. Example CF field potentials. $A$, Responses evoked by hindpaw stimulation at recording positions $1-6$ in $C P$ in an example case (recording loci are depicted on a posterior view of the rat cerebellum shown at the bottom of the figure). Each recording site shows three consecutive sweeps superimposed. Left and right columns show responses evoked by stimulation of the medial and lateral sides of the ipsilateral hindpaw, respectively. $\boldsymbol{B}$, Schematic summarizing location of somatotopically defined regions within the $\mathrm{C} 1$ zone in the ipsilateral CP. Approximate mediolateral width of $C 1$ zone in CP is shown. C, caudal; I, lateral; lat hp, lateral hindpaw; m, medial; med hp, medial hindpaw; PML, paramedian lobule; r, rostral, VIII, vermal lobule 8.

(Fig. 2A). Medially, stimulation of the medial side of the ipsilateral hindpaw evoked a large field potential, whereas stimulation of the lateral side of the ipsilateral hindpaw evoked little or no response. Further lateral in $\mathrm{CP}$, the field responses evoked by stimulation of the medial hindpaw reduced in size until they became absent, but stimulation of the lateral hindpaw evoked progressively larger responses.

Based on a synthesis of all available cases, the hindlimb $\mathrm{C} 1$ zone could be subdivided into three somatotopically defined regions. Each region was identified in terms of the ipsilateral hindpaw territory that consistently evoked the largest cerebellar response (see Materials and Methods). From medial to lateral, these were heel, medial paw, and lateral paw (Fig. 2B), with response onset latencies of $18.1 \pm 3.0 \mathrm{~ms}$ (mean $\pm \mathrm{SD}, n=5), 16.7 \pm 2.2 \mathrm{~ms}(n=8)$, and $19.0 \pm 2.1 \mathrm{~ms}(n=10)$, respectively. These latencies were not statistically different ( $p=0.34$, one-way ANOVA).

Using the field potential mapping technique, it was not possible to determine reliably the mediolateral width of different re- gions within the broader $\mathrm{C} 1$ zone in $\mathrm{CP}$ (see Discussion). However, in terms of spatial localization in the cortex, 22 physiologically identified "hotspots" relating approximately to the center of individual regions could be related to postmortem identification of Retrobeads injection site position. The mediolateral location of individual injection sites was normalized using a laterality index (see Materials and Methods). The three regions were centered from medial to lateral as follows: heel $(0.21 \pm 0.1$, mean $\pm \mathrm{SD}, n=5)$, medial paw $(0.40 \pm 0.1 \mathrm{SD}, n=8)$, and lateral paw $(0.54 \pm 0.1 \mathrm{SD}, n=9)$. These values were statistically significant $(p<$ 0.0001, one-way ANOVA; also see below).

\section{General features of injection sites}

A total of 54 injections of tracer material were made into the cortex of CP in 25 rats (Tables 1, 2; Fig. 1C-F). Tables 1 and 2 show that almost all injection sites (96\%) were at a microzonal level of resolution (i.e., $\leq 0.3 \mathrm{~mm}$ in mediolateral width). The mediolateral width of individual injection sites of BDA measured from 15 to $200 \mu \mathrm{m}$, whereas Retrobeads injection sites ranged from 50 to $490 \mu \mathrm{m}$ (Tables 1 , $2)$. Paired injection sites $(n=14)$, in which one color of Retrobeads and BDA were injected at the same cortical location (see Materials and Methods), were similar in size in mediolateral width (BDA, $104 \pm$ $50 \mu \mathrm{m}$, mean $\pm \mathrm{SD}, n=14$; Retrobeads, $119 \pm 61, n=14$; Table 1 ). In paired injections, we used the visible spot of Retrobeads as a target for injecting the BDA tracer, so the two injections were usually closely aligned (Fig. 1E) but, in some cases, there was a small distance between them (see Discussion).

Of the 54 injections of tracer material, a total of 44 were made into the approximate center of each of the somatotopically identified regions within $\mathrm{C} 1$. Because in all injections, the tracer material was delivered to the most superficial part of the injected folium, it is likely that they involved those parts of the cortex involved in generating the surface recorded field potentials. Consistent with this assumption was the finding, postmortem, that injection sites were always located in the most superficial PC layer and/or molecular/granular layers with minimal spread to the underlying white matter (Fig. $1 C-F$ ).

\section{Correlation between somatotopically defined regions and zebrin bands}

If the microcircuit architecture of the cerebellar cortex has any relation to physiological compartmentation, then it might be expected that a correlation would be present between PC phenotype and the spatial organization of the somatotopically defined regions described above. To investigate this possibility, we focused on the spatial distribution of zebrin II because it is the most comprehensively studied PC molecular marker. The analysis was 
confined to those cases $(n=21)$ in which the physiological responses at a given recording site were evoked preferentially from one part of the ipsilateral hindpaw. This was taken to correspond approximately to the center of a particular somatopically defined region within $\mathrm{C} 1$. The cortical recording site position was related postmortem to the pattern of zebrin banding by reference to the associated Retrobeads injection site. From medial to lateral in the cortex, 3 of 5 (60\%) "heel" cases were related to zebrin band $\mathrm{f}-$, 4 of 7 (57\%) "medial paw" cases were related to zebrin band e1-, and 6 of $9(67 \%)$ "lateral paw" cases were related to zebrin bands $\mathrm{e} 2+/ \mathrm{e} 2-$.

Therefore, based on postmortem localization of injection sites guided by the electrophysiological mapping, there appeared to be at least some correlation between somatotopy within the $\mathrm{C} 1$ zone in $\mathrm{CP}$ and zebrin band identity.

\section{Relationship between all injection sites and zebrin bands}

The suggestion of a relationship between zebrin banding and physiological responses encouraged us to use zebrin as a frame of reference to compare PC inputs and outputs, thereby comparing the organization of the various maps within the cerebellar cortex at a microcircuit level of resolution. We grouped all available injection sites in relation to the zebrin banding. A total of 44 injection sites were judged to be confined within individual zebrin bands within the cortex of CP. From medial to lateral, the zebrin band and related number of cases (in parentheses) was as follows: $4+(n=1), 4-(n=2), \mathrm{f}+(n=3), \mathrm{f}-(n=7), \mathrm{e} 1+$ $(n=11), \mathrm{e} 1-(n=9), \mathrm{e} 2+(n=8)$, and $\mathrm{e} 2-(n=3)$. The relationship between individual injection sites and the zebrin banding was determined by measuring the laterality index of each injection site relative to $4+$ (see Materials and Methods). This approach was validated by the finding that, in those cases in which the pattern of immunostaining around the injection site showed the zebrin band clearly, the zebrin identity of the injection site was the same as judged by the laterality index.

Of the total number of available cases $(n=44)$ judged to be restricted to individual zebrin bands, 17 were Retrobeads injections and the remaining 27 were BDA injections. For 16 of the 17 Retrobeads injections, almost all of the cell labeling (99\%) in the contralateral inferior olive was confined to the ventral leaf of the DAO (vDAO). Given the cortical location of these injections in zebrin bands $\mathrm{f}+, \mathrm{f}-, \mathrm{e} 1+, \mathrm{e} 1-$, and $\mathrm{e} 2+$ of $\mathrm{CP}$ (Fig. 3 ) and the known mediolateral extent of the $\mathrm{C} 1$ zone in this lobule (Atkins and Apps, 1997), this cell labeling was therefore interpreted as the result of retrograde axonal transport from the $\mathrm{C} 1$ zone (Trott et al., 1998; Sugihara and Shinoda, 2004).

The 10 cases (Retrobeads, $n=8$; BDA, $n=2$ ) that were not restricted to a single zebrin band were either centered on one zebrin band with some spread to an adjacent band (e.g., 23GBBDA) or spread across two zebrin bands (e.g., 16RB). Of the eight Retrobeads cases, four had injections placed laterally in the cortex, which resulted in some olive cell labeling located in caudal and middle parts of medial accessory olive. The cell labeling was therefore derived from retrograde axonal transport from inclusion of the CX zone, which corresponds to zebrin band e2(Sugihara and Shinoda, 2004), and possibly the C2 zone, which corresponds to zebrin band 5+ (Sugihara and Shinoda, 2004) in the effective injection site (Buisseret-Delmas et al., 1993; Atkins and Apps, 1997).

\section{Olivocerebellar microcircuits are related to zebrin bands}

After identifying the position of injection sites in relation to their zebrin banding, we next determined the spatial distribution of retrogradely labeled cells in the contralateral inferior olive. This allowed us to determine the territory within the olive that provides CFs to the particular zebrin band under study. Given that the injection sites were at a microzonal level of resolution (see above), this meant that the analysis related olivocerebellar microcircuits to zebrin bands. We focused on those zebrin bands in CP in which the injection sites resulted in retrograde cell labeling within vDAO, i.e., the part of the inferior olive associated with the C1 zone (Atkins and Apps, 1997; Pijpers et al., 2006; Voogd et al., 2003; Fig. 3).

Retrobeads injection sites restricted or centered within $\mathrm{f}-(n=5), \mathrm{e} 1+(n=6), \mathrm{e} 1-(n=7)$, and $\mathrm{e} 2+(n=5)$ resulted in cell labeling within the centrolateral, caudolateral, caudocentral, and rostrocentral parts, respectively, of vDAO (Fig. 3B-E). This fine grain topography is especially evident in the pooled cases (Fig. $3 G$ ) and suggests that distinct territories within the lateral half of vDAO (which tend to form rostrocaudally oriented columns of cells) provide CF input to individual zebrin bands. Areas of highest cell density are represented in Figure $3 H$ by the corresponding colored squares in the grid (for details of quantitative analysis, see Materials and Methods). This grid square analysis supports the topographical organization seen in the pooled maps for each zebrin band and is consistent with a detailed (microcircuit) $\mathrm{CF}$ topography within the $\mathrm{C} 1$ zone in $\mathrm{CP}$ in the rat cerebellum.

The results from double retrograde tracer studies $(n=10$ animals) in which red and green Retrobeads were injected into different zebrin bands supports this interpretation. In these experiments, little or no overlap of the two territories of singlelabeled cells in the inferior olive was found (Fig. $3 F$ ). Overlaps expressed as a percentage of the territory occupied by the smaller, single-labeled cell population were on average just $6.3 \%$ (range in individual experiments, $0-18.2 \%$; Table 3 ). This finding, combined with the presence of few or no double-labeled cells (a total of 23 double-labeled cells were found across all double tracer experiments, representing on average $2.6 \%$ of the total labeled cell population), can be taken as further evidence to suggest that a detailed topographical organization exists within the CF projection to the $\mathrm{C} 1$ zone in $\mathrm{CP}$ of the rat cerebellum.

\section{Corticonuclear microcircuits are related to zebrin bands}

Using data derived from the same experiments described above, we next determined whether the fine grain (microcircuit) topography also extended to PC anterograde projections to the cerebellar nuclei. The nanoinjections of BDA resulted in the labeling of several PC axons that could be traced through the white matter before entering and branching in the cerebellar nuclei to form en-passant and terminal swellings (Fig. 1I). We focused on axons that terminate in the cerebellar nuclei and not on those that run ventrally past the cerebellar nuclei, because the latter are presumed to be MF or CF axons. Figure 4 shows representative cases. BDA injections into zebrin band $\mathrm{f}+(n=3), \mathrm{f}-(n=3), \mathrm{e} 1+$ $(n=7)$, e $1-(n=3)$, and $\mathrm{e} 2+(n=7)$ resulted in terminal labeling in the following locations in anterior interpositus nucleus (AIN): rostrocentral/medial, caudocentral/medial, caudomedial, central, and rostrocentral, respectively. This topography is also evident in the pooled cases (Fig. 5) and when the area of greatest overlap of the terminal labeling in the cerebellar nuclei for each group was calculated (Fig. 5, grid square inset). This suggests that the precise pattern of connectivity within CF inputs to individual zebrin bands within the $\mathrm{C} 1$ zone in $\mathrm{CP}$ is preserved in PC outputs to distinct territories within AIN in the rat cerebellum. 

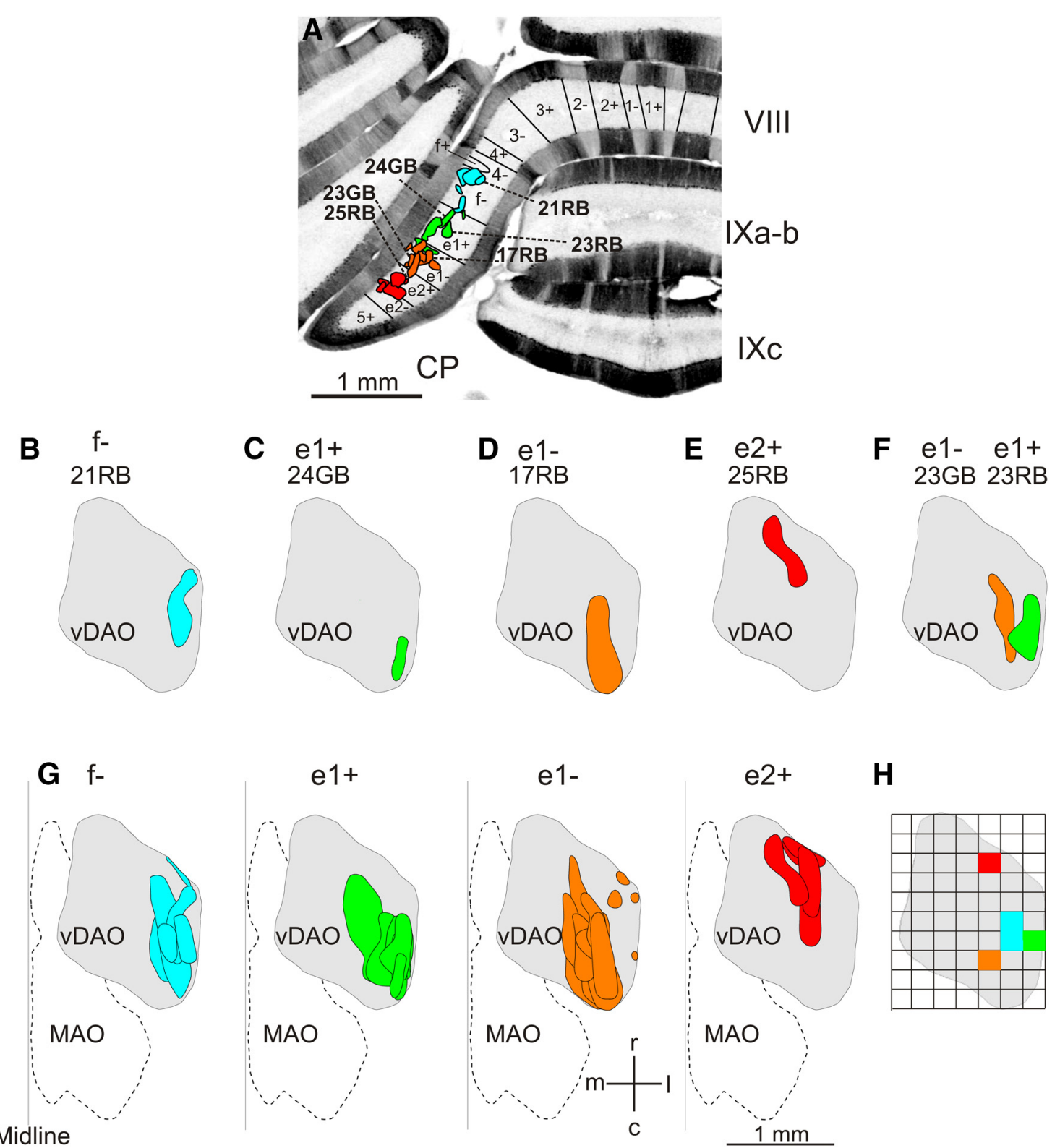

Figure 3. Retrograde olive cell labeling. $\boldsymbol{A}$, Photomicrograph of a coronal section of the rat posterior cerebellum labeled with zebrin and showing the location of all Retrobead injection sites. Injection sites in zebrin $\mathrm{f}$ - are shown in blue, injections sites in e1 + are in green, injection sites in e1 - are in orange, and injection sites in e2 + are in red. Individual injections sites for cases shown in $\boldsymbol{B}-\boldsymbol{F}$ are identified. $\boldsymbol{B}-\boldsymbol{E}$, Spatial distribution of olive cell labeling depicted on standard horizontal maps of right vDAO for individual cases. Cell labeling after a Retrobead injection into zebrin band $\mathrm{f}-(\boldsymbol{B}), \mathrm{e} 1+(\boldsymbol{C}), \mathrm{e} 1-(\boldsymbol{D})$, and e2 $+(\boldsymbol{E})$. $\boldsymbol{F}$, 0live cell labeling after double tracer Retrobead injections into zebrin band e1 - (orange) and e1+ (green). $\boldsymbol{G}$, Pooled data showing spatial distribution of olive cell labeling for all cases centered on the different zebrin bands. $\boldsymbol{H}$, Quantitative analysis comparing the distribution of olive cell labeling for cases centered on the different zebrin bands. The standard horizontal map of vDA0 was subdivided into a grid, with each square $200 \mu \mathrm{m}$ by $200 \mu \mathrm{m}$. Same color scheme as in $\boldsymbol{A}-\boldsymbol{G}$ showing location of highest average density of olive cell labeling for injection sites centered on $\mathrm{f}-, \mathrm{e} 1+, \mathrm{e} 1-$, and e2 +. c, caudal; l, lateral; m, medial; MA0, medial accessory olive; r, rostral.

Further evidence to support the presence of a detailed organization within olivo-cortico-nuclear projections in $\mathrm{CP}$ can be found in those additional cases $(n=6)$ in which the injection site involved two adjacent zebrin bands (two zebrin bands denoted by " $\&$ " or " $>$ " in Tables 1,2$)$. In such cases, the pattern of olive and cerebellar nuclear labeling was consistent with the topography detailed above. For example, in Retrobeads case 31RB, in which the injection site included $\mathrm{e} 1-$ and $\mathrm{e} 2+$, the pattern of retrogradely labeled olive cells was found in the caudocentral and rostrocentral parts of vDAO, consistent with restricted e1- and e2 + cases, respectively (Fig. 6Cii). In addition, cases in which the injection site was centered on a specific zebrin band but the injection site of Retrobeads and/or BDA spread medially or laterally to involve a neighboring zebrin band $(n=4)$ resulted in a pattern of olive and cerebellar nuclear labeling consistent with the topography detailed above. For example, in case 21RB-BDA, in which the BDA injection site was centered on $\mathrm{e} 1+$ with some spread to $\mathrm{f}-$, the pattern of terminal labeling was mainly in caudomedial parts of AIN, which is consistent with restricted e1+ cases, but there was also some labeling in caudocentral parts of AIN, which is consistent with inclusion of zebrin band $\mathrm{f}-$.

BDA injections were also made in zebrin bands on either side of the $\mathrm{C} 1$ zone in CP. A BDA injection $(n=1)$ into zebrin band $4+$ (Fig. 4) labeled terminals in the ventromedial part of posterior interposed nucleus and BDA injections $(n=2)$ into zebrin band 4- (Fig. 4) labeled terminals in the dorsal part of the lateral 
Table 3. Retrograde cell counts in inferior olive and BPN

\begin{tabular}{|c|c|c|c|c|c|c|}
\hline \multirow[b]{2}{*}{ Case } & \multicolumn{5}{|c|}{ Olive cell counts } & \multirow{2}{*}{$\begin{array}{l}\text { BPN } \\
\text { counts }\end{array}$} \\
\hline & MAO & DAO & P0 & Total & Double-labeled (\% of total) & \\
\hline $7 G B$ & 6 & 54 & 0 & 60 & & \\
\hline $11 R B$ & 1 & 112 & 0 & 113 & & \\
\hline $12 \mathrm{~GB}$ & 0 & 33 & 0 & 33 & & 26 \\
\hline $12 \mathrm{RB}$ & 3 & 103 & 1 & 105 & $6 / 144(4.2 \%)$ & 167 \\
\hline $14 G B$ & 20 & 27 & 0 & 47 & & \\
\hline $14 \mathrm{RB}$ & 0 & 29 & 0 & 29 & $0 / 76(0 \%)$ & 352 \\
\hline $16 \mathrm{RB}$ & 94 & 7 & 0 & 101 & & 463 \\
\hline 17RB & 0 & 48 & 0 & 48 & & \\
\hline $18 G B$ & 0 & 38 & 0 & 38 & & \\
\hline $20 \mathrm{RB}$ & 52 & 47 & 0 & 99 & & \\
\hline $20 G B$ & 0 & 16 & 0 & 16 & $0 / 115(0 \%)$ & \\
\hline $21 R B$ & 0 & 23 & 0 & 23 & & \\
\hline $22 \mathrm{~GB}$ & 0 & 9 & 0 & 9 & & \\
\hline $23 \mathrm{RB}$ & 0 & 82 & 0 & 82 & & \\
\hline $23 G B$ & 0 & 25 & 0 & 25 & $3 / 110(2.7 \%)$ & \\
\hline $24 R B$ & 0 & 61 & 0 & 61 & & \\
\hline $24 G B$ & 0 & 13 & 0 & 13 & $2 / 76(0 \%)$ & \\
\hline $25 \mathrm{RB}$ & 0 & 33 & 0 & 33 & & \\
\hline $25 G B$ & 0 & 46 & 0 & 46 & 0/79 (0\%) & \\
\hline 31RB & 0 & 26 & 0 & 26 & & 201 \\
\hline $31 G B$ & 5 & 7 & 0 & 12 & $0 / 38(0 \%)$ & 113 \\
\hline $32 \mathrm{RB}$ & 0 & 69 & 0 & 69 & & 171 \\
\hline $32 G B$ & 0 & 140 & 0 & 140 & $12 / 221(5.4 \%)$ & 75 \\
\hline $36 \mathrm{RB}$ & 0 & 20 & 0 & 20 & & $19^{\dagger}$ \\
\hline $36 G B$ & 0 & 23 & 0 & 23 & $0 / 43(0 \%)$ & 77 \\
\hline
\end{tabular}

Retrograde cell counts in the inferior olive and BPN. Double-labeled values indicate number of double-labeled cells expressed as a percentage of the total number of labeled cells in that case. ${ }^{\dagger}$ One double-labeled cell included in cell count. BPN, Basilar pontine nuclei; $\mathrm{DA0}$, dorsal accessory olive; $\mathrm{MA0}$, medial accessory olive; $\mathrm{PO}$, principal olive.

vestibular nucleus (LVN) and in the junction between the LVN and the AIN (an area termed the anterior interstitial cell group; Sugihara and Shinoda, 2004). LVN and anterior interstitial cell group have previously been shown to be the target of PCs in zone $\mathrm{B}$ (zebrin band 2-) in the anterior lobe (Sugihara and Shinoda, 2004). BDA injections $(n=3)$ into zebrin band $\mathrm{f}+$ resulted in terminal labeling within rostral and medial parts of AIN (Fig. 4). Finally, BDA injections $(n=3)$ into zebrin band e2- resulted in terminal labeling in dorsomedial posterior interposed nucleus (Fig. 4), which is the target of PCs in zone CX and C2 (Sugihara and Shinoda, 2004).

In sum, at a microcircuit level of resolution, the inputs and outputs from the inferior olive and to the cerebellar nuclei appear to be associated with individual zebrin bands of PCs, which is consistent with the one-map hypothesis.

\section{Pontocerebellar microcircuits are related to zebrin bands}

For the one-map hypothesis to hold true, the spatial alignment between olivocerebellar and corticonuclear projections and PC phenotype should also be present in the connectivity of MF inputs. We therefore also examined the spatial distribution of retrogradely labeled cells in the BPN, which is the principal source of MFs to the cerebellum (Brodal and Bjaalie, 1997; Cicirata et al., 2005). Data were obtained from 10 cases in which injections of red and green Retrobeads were made into $\mathrm{CP}$, of which four cases involved zebrin band $\mathrm{e} 1+$ and four cases involved e $2+$. As detailed above, olive cell labeling was mainly confined within the caudolateral part of vDAO or within the rostrocentral part of vDAO. Almost all (99.7\%) of the retrograde cell labeling within the pons was confined to the caudal half of the contralateral BPN (Fig. 6; Table 3).

There were a total of three double tracer experiments in which sufficient retrograde transport occurred to compare reliably the patterns of spatial distribution of the two single-labeled cell populations in BPN (Table 3). In one of these, the red injection was centered on $\mathrm{e} 1+$ and the green injection was centered on e2+ and there was limited overlap between the two single-labeled BPN cell populations (Fig. 6Ai-Aiii, the area of overlap represented only $5.4 \%$ and $4.0 \%$ of the two BPN single-labeled territories). In contrast, in a double tracer experiment in which the red and green injection sites were contiguous and centered on the same zebrin band (Fig. 6Bi-Biii, el+), there was more extensive overlap of the two single-labeled BPN cell territories $(31.3 \%$ and $81.5 \%$ overlap). Finally, a double tracer experiment in which the red injection site was located in $\mathrm{e} 1-$ and $\mathrm{e} 2+$ and the green injection site was centered laterally in e $2+$ with some spread to e2- (Fig. 6Ci-Ciii) resulted in moderate overlap of the two single-labeled territories ( $13.3 \%$ and $8.1 \%$ overlap). There was a strong positive correlation $\left(r^{2}=0.74, p=0.028, n=6\right)$ between the degree of overlap in BPN and overlap of the two single-labeled cell populations in vDAO, indicating that the pontocerebellar projection is aligned to the olivocerebellar projection at a microcircuit level of resolution.

When all available cases centered on the same zebrin band were pooled, clusters of BPN cell labeling tended to merge into larger territories. Figure $7 A, B$ shows, respectively, the total area within BPN occupied by labeled cells for all cases centered on $\mathrm{e} 2+(n=4)$ and for all cases centered on e1+ $(n=4)$. Compared with $\mathrm{e} 2+$ cases, the territory occupied by cell labeling in e1+ cases extends more caudally in BPN. Figure $7 C$ shows "core" areas - the territories within BPN where cell labeling was present in at least three cases. The core areas generally formed discrete clusters of cell labeling and overlaps between the two groups represented $13.1 \%$ of the core territory for e $2+$ cases and $6.6 \%$ of the core territory for e $1+$ cases, indicating that they occupied mainly separate areas in BPN (Fig. 7C).

There was no correlation between BPN and total olive cell counts $\left(r^{2}=0.05, p>0.05, n=10\right)$ and, in some cases, cell labeling was present in the olive but none was detected in the pons. This was presumably because the effective injection site in such cases was mainly within the molecular layer and/or there was less tracer uptake in MF afferents.

\section{Additional evidence of microcircuit connectivity relating to zebrin banding}

The experiments detailed above using tracer injections into the cerebellar cortex provide evidence for a microcircuit organization within the input-output connectivity of the $\mathrm{C} 1$ zone in $\mathrm{CP}$ associated with the zebrin phenotype of PCs. If this relationship is genuine, then it would be expected that injections of retrograde tracer into restricted territories within AIN should result in labeling of PCs confined to individual zebrin bands within CP. This was tested in five additional experiments in which a retrograde tracer injection $(\sim 2$ nl) was targeted within medial AIN. In one of these experiments (Case \#590; Fig. 8), two (red and green) Retrobeads injections were both localized to different parts of medial AIN (Fig. 8A-C). Based on the cortical tracer results, the red injection site was centered on the termination area associated with zebrin band $\mathrm{e} 1+$, whereas the injection of green Retrobeads was centered on a more central area of AIN associated with zebrin band e1-.

PCs retrogradely labeled by red Retrobeads were distributed mainly in zebrin band e1+ in CP (Fig. 8G,I,J,L, black arrowheads), with 293/614 (48\%) of the cell labeling in a sample of 12 consecutive sections (although cells were also labeled in $\mathrm{f}-$ and e1- at $31 \%$ and $21 \%$ of the cell labeling, respectively). PCs retrogradely labeled by green Retrobeads were distributed predom- 
4+ 559rtcop
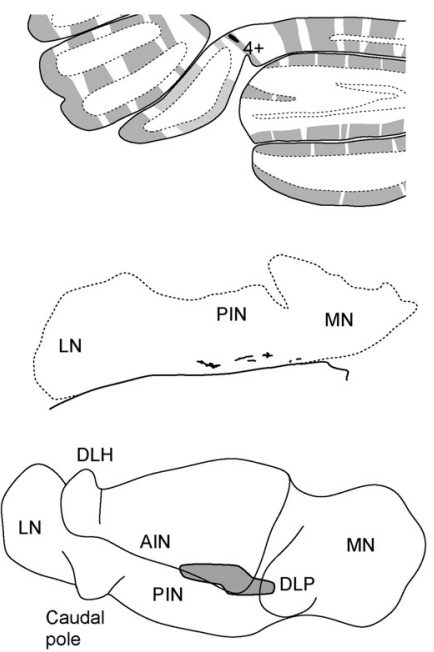

f- $22 \mathrm{~GB}-\mathrm{BDA}$
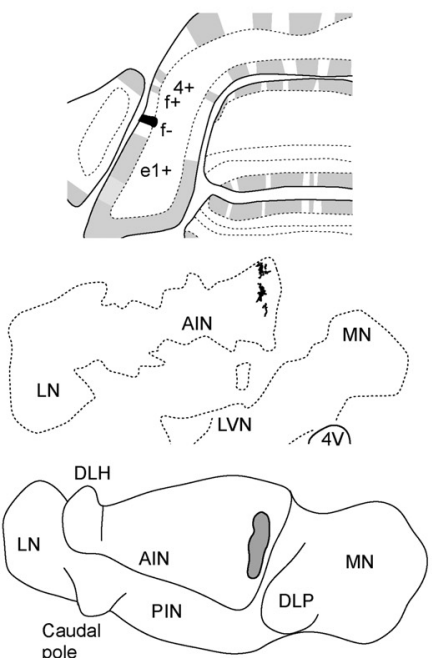

4- $23 B D A$
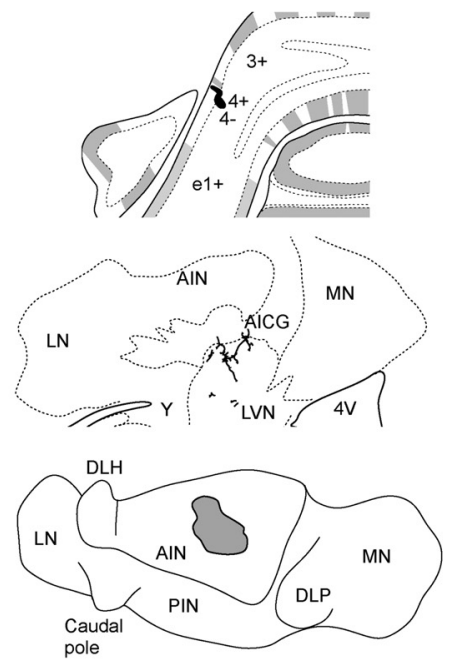

e1+ $12 \mathrm{~GB}-\mathrm{BDA}$
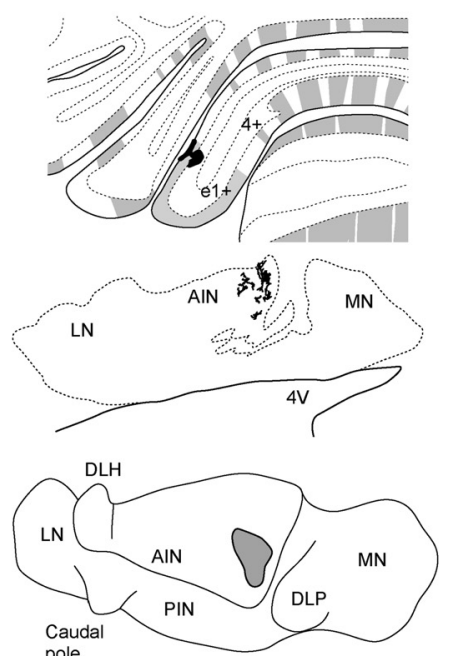

$\mathbf{f +}$ 25BDA
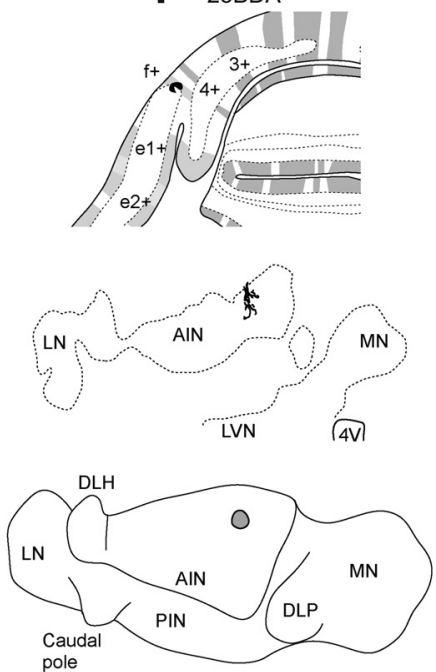

e1- 17RB-BDA
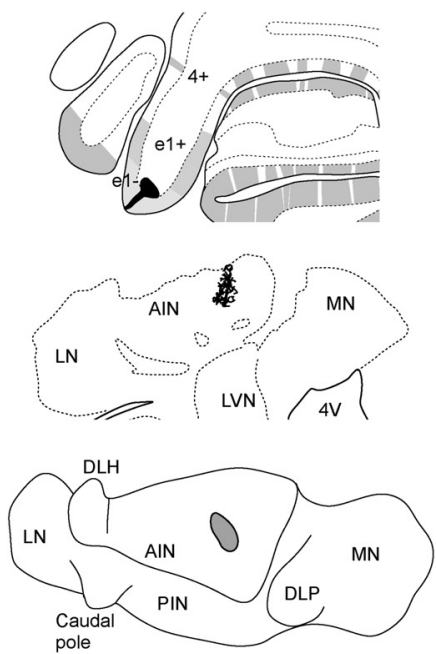

e2+ 559 rtcop
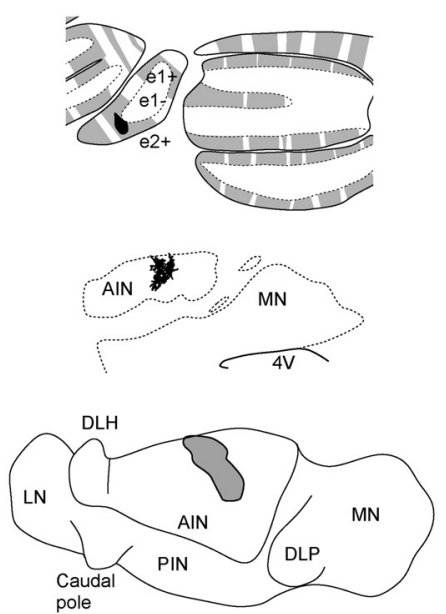

e2- $567 \mathrm{rtcop}$
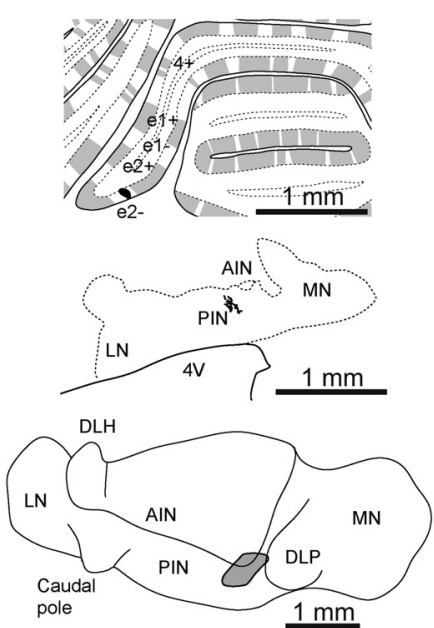

Figure 4. PC terminal labeling. Mapping of individual cases of corticonuclear projections relative to zebrin bands. For each example case of an injection site centered on a specific zebrin band, the top panel shows the injection site in black plotted on a coronal view of the rat posterior cerebellum, the middle panel shows a camera lucida drawing of a single coronal section depicting the location of labeled axon preterminals/terminals in the ipsilateral (left) cerebellar nuclei, and the bottom panel shows on a horizontal view of the left cerebellar nuclei. The total distribution of labeled preterminals/terminals is shown as a gray shaded area. 4V, fourth ventricle; AICG, anterior interstitial cell group; AIN, anterior interposed nucleus; d, dorsal; DLH; dorsolateral hump (of the AIN); DLP, dorsolateral protuberance (of the MN);I, lateral; LN, lateral (dentate) nucleus; LVN, lateral vestibular nucleus; m, medial; PIN, posterior interposed nucleus; MN, medial (fastigius) nucleus; r, rostral; v, ventral; Y, nucleus Y. 
f-
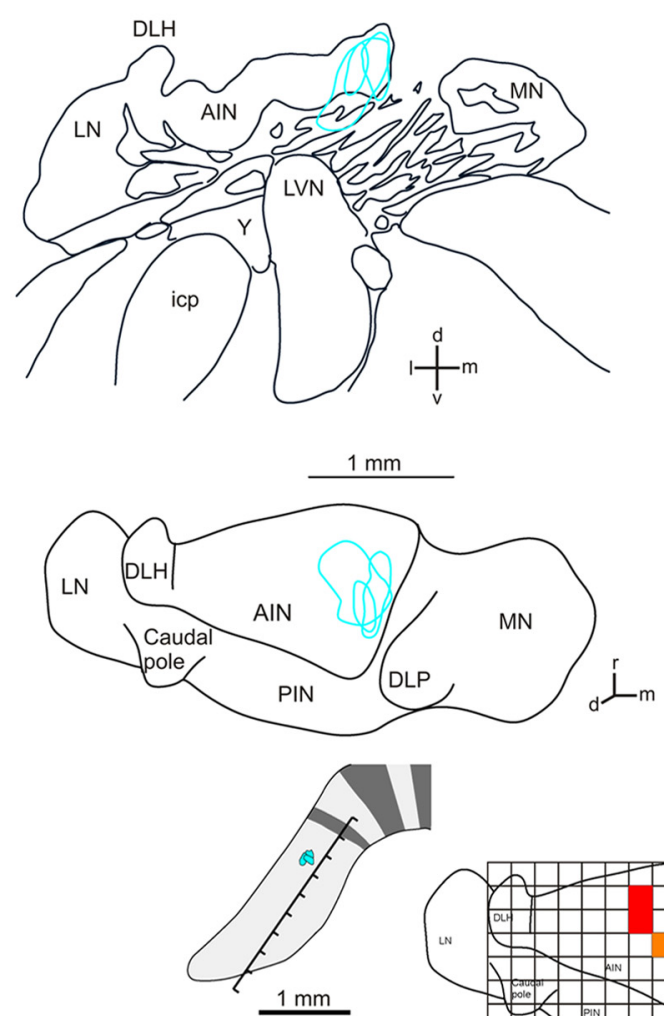

$\mathrm{e}^{1+}$
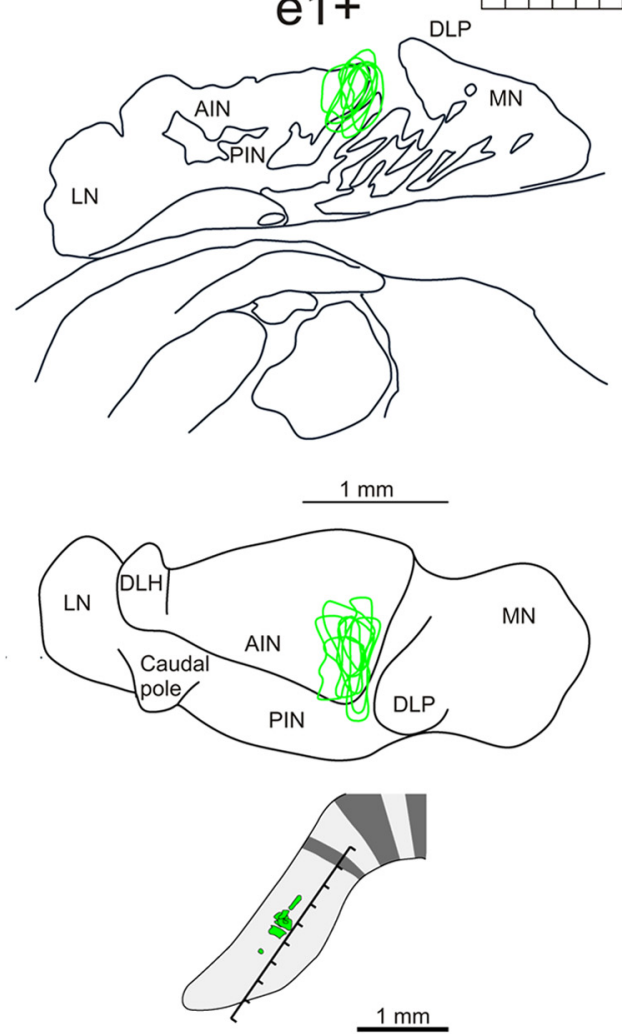

\section{e1-}
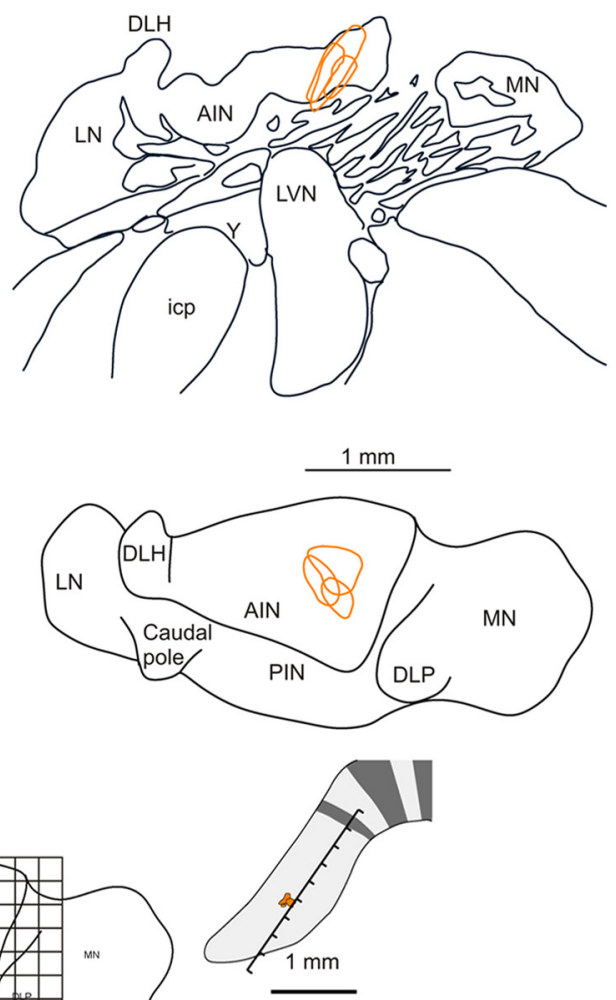

e2+
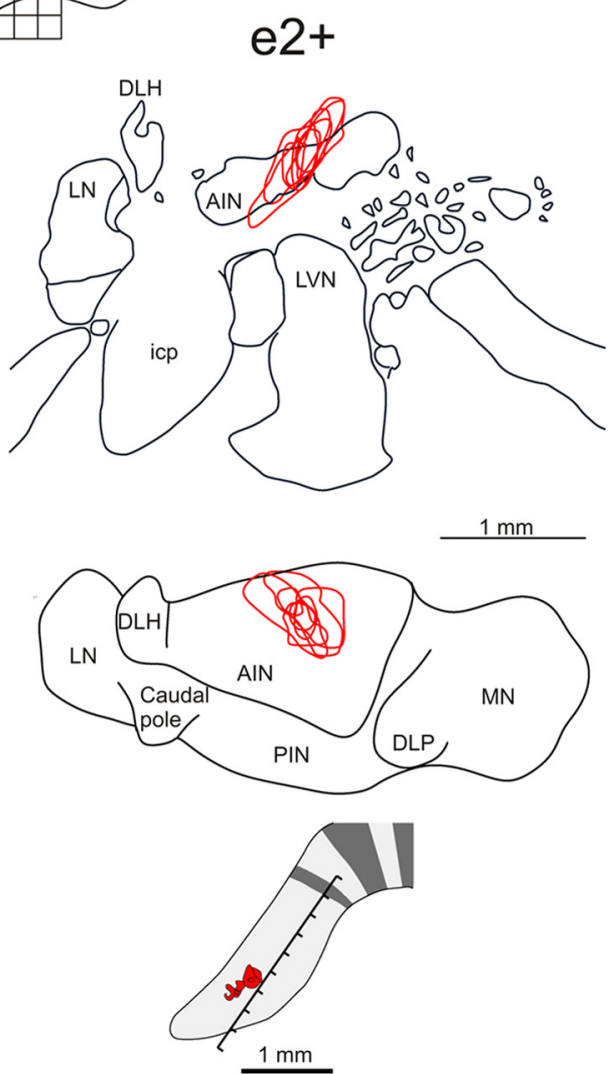

Figure 5. Pooled cases of corticonuclear projections associated with different zebrin bands in the C1 zone in CP. Each group of maps shows the territory occupied by labeled corticonuclear preterminals/terminals in coronal (upper) and horizontal (middle) views of the left cerebellar nuclei. Bottom panel shows the injection sites on a schematic of CP. Inset in center of figure shows the horizontal view of cerebellar nuclei overlayed with a grid $(0.2 \mathrm{~mm} \times 0.2 \mathrm{~mm}$ square grating). The corresponding colored squares in AIN show for all cases centered or restricted on a given zebrin band where the greatest overlap of terminal labeling occurred. AIN, anterior interposed nucleus; DLH; dorsolateral hump (of the AIN); d, dorsal; DLP, dorsolateral protuberance (of the MN); icp, inferior cerebellar peduncle; I, lateral; LN, lateral (dentate) nucleus; LVN, lateral vestibular nucleus; $m$, medial; PIN, posterior interposed nucleus; MN, medial (fastigius) nucleus; r, rostral; $v$, ventral;, , nucleus Y. 


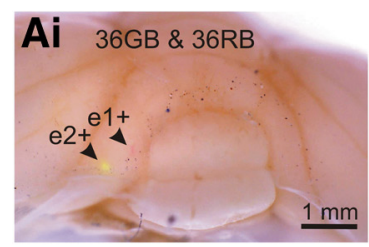

Aii

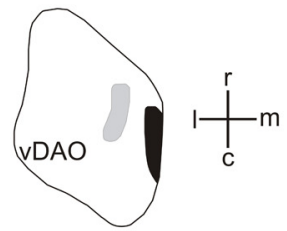

Aiii
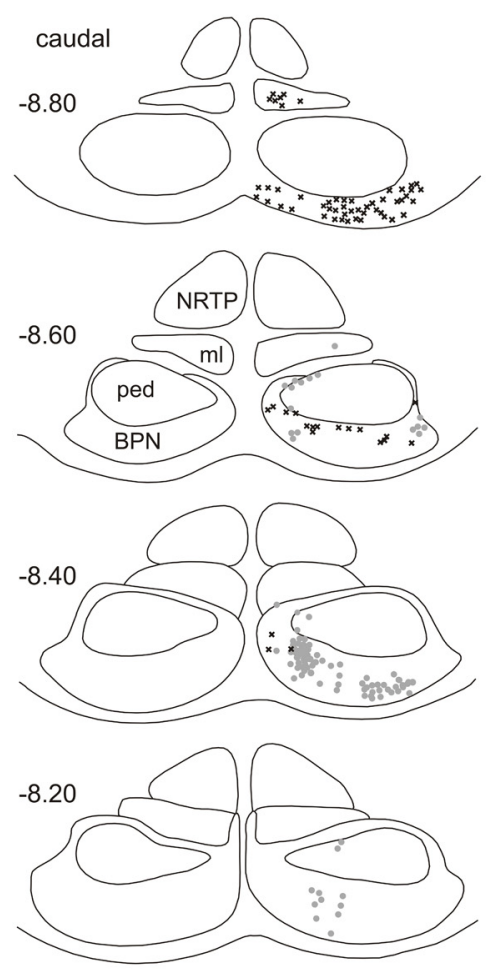

rostral

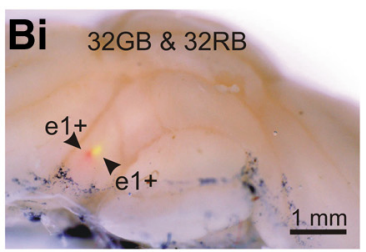

$\mathrm{Bii}$

\section{Biii}
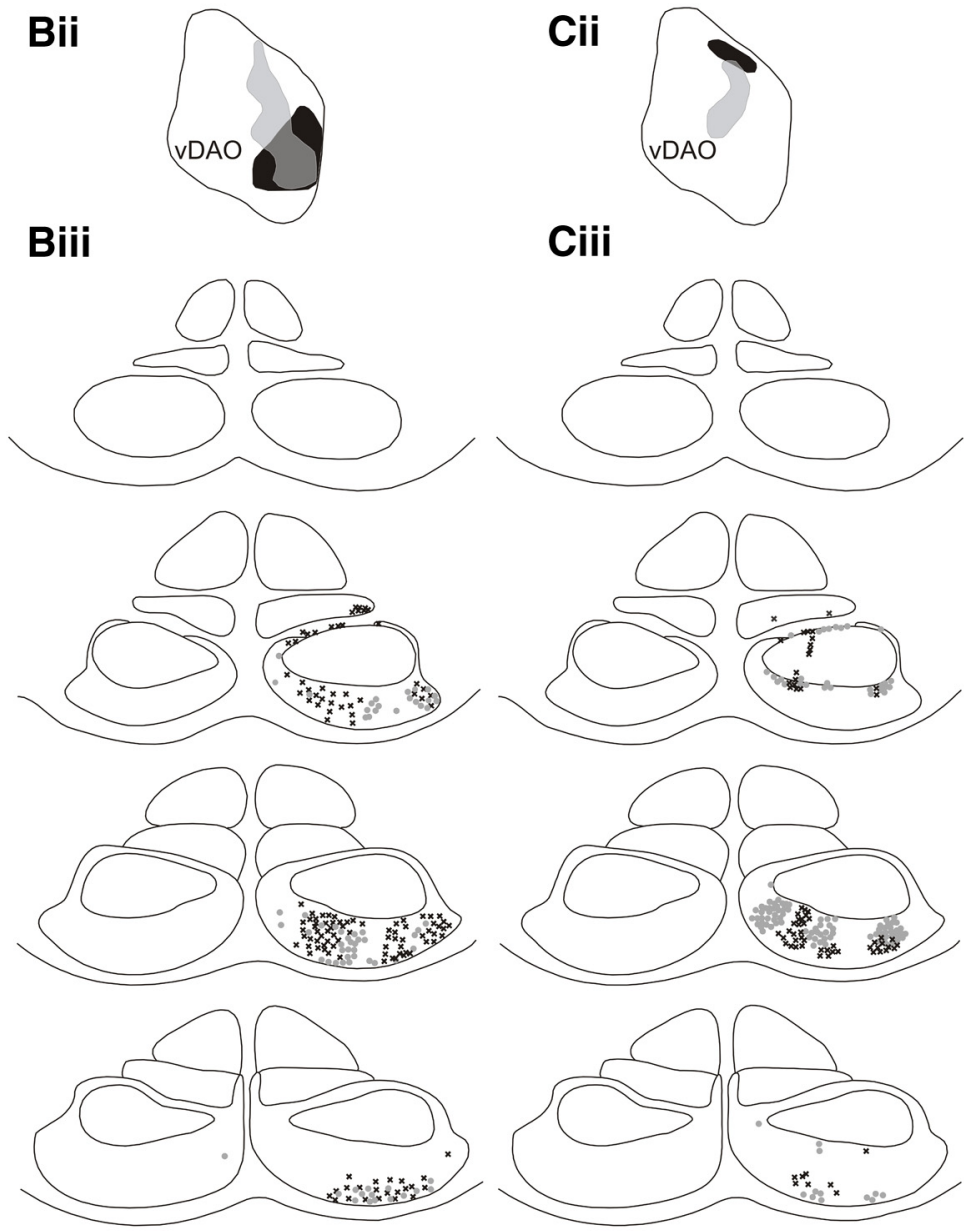

Figure 6. Retrograde cell labeling in the pons. Ai, Photomicrograph of posterior lobe of the rat cerebellum showing red and green Retrobeads injections in e1+ and e2 + , respectively. Aii, Standard horizontal map of vDAO showing territory occupied by olive cells retrogradely labeled with green Retrobeads (light gray) and red Retrobeads (black). Aiii, Distribution of retrogradely labeled pontine cells plotted on standard transverse maps ( $0.2 \mathrm{~mm}$ interval between maps, APlevels -8.2 to -8.8 ). Each symbol indicates a labeled cell (black crosses denote red-labeled cells, gray

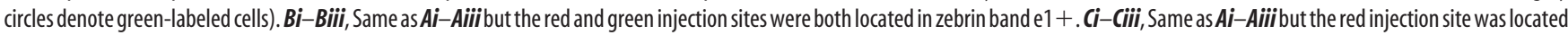
in zebrin bands e 1 - and e2 + and the green injection site was located in zebrin band e2 + with spread to neighboring e2 - BPN, Basilar pontine nuclei; $\mathrm{c}$, caudal; l, lateral; $\mathrm{m}$, medial; $\mathrm{ml}$, medial lemniscus; ped, cerebral peduncle; NRTP, nucleus reticularis tegmenti pontis; r, rostral.

inantly in zebrin band e1- (Fig. $8 H, I, K, L$, white arrowheads) with $223 / 433$ (52\%) of the cell labeling in a sample of 12 consecutive sections, but less dense cell labeling was also present in zebrin bands e $1+, \mathrm{f}-$, and $\mathrm{e} 2+(24 \%, 18 \%$, and $6 \%$ of the cell labeling respectively). Consistent with the cortical tracer results, these experiments therefore indicate that zebrin band $\mathrm{e} 1+$ and the neighboring band $\mathrm{e} 1$ - mainly project to the most medial part and the neighboring more central part of AIN, respectively.

In the inferior olive, neurons retrogradely labeled by red Retrobeads were located mainly in the lateral part of vDAO (Fig. $8 D, F$, black arrowheads), which coincided with the distribution of neurons projecting to zebrin band $\mathrm{e} 1+$ in CP. Olive neurons labeled by green Retrobeads were located mainly in a more medial area in vDAO (Fig. 8E,F, white arrowheads), which coincided with the distribution of neurons projecting to zebrin band $\mathrm{e} 1-$ in CP. A few neurons were also labeled in the medial accessory olive and in the principal olive. Whether this additional cell labeling was due to tracer uptake by passing axons is not clear.

The remaining cerebellar nuclear injections were also generally consistent with the topographic relationship of the corticonuclear projection from CP revealed in the anterograde labeling experiments detailed above. For example, an injection in the caudomedial AIN resulted in retrograde labeling of PCs in zebrin band e1 $+(\# 575)$ and an injection into central AIN labeled PCs in zebrin band e1- (\#578).

The results from cerebellar nuclear injections therefore support the general conclusion that there is a detailed pattern of corticonuclear connectivity in the $\mathrm{CP}$ in rat. The results also suggest that this fine grain topographical relationship can be ex- 


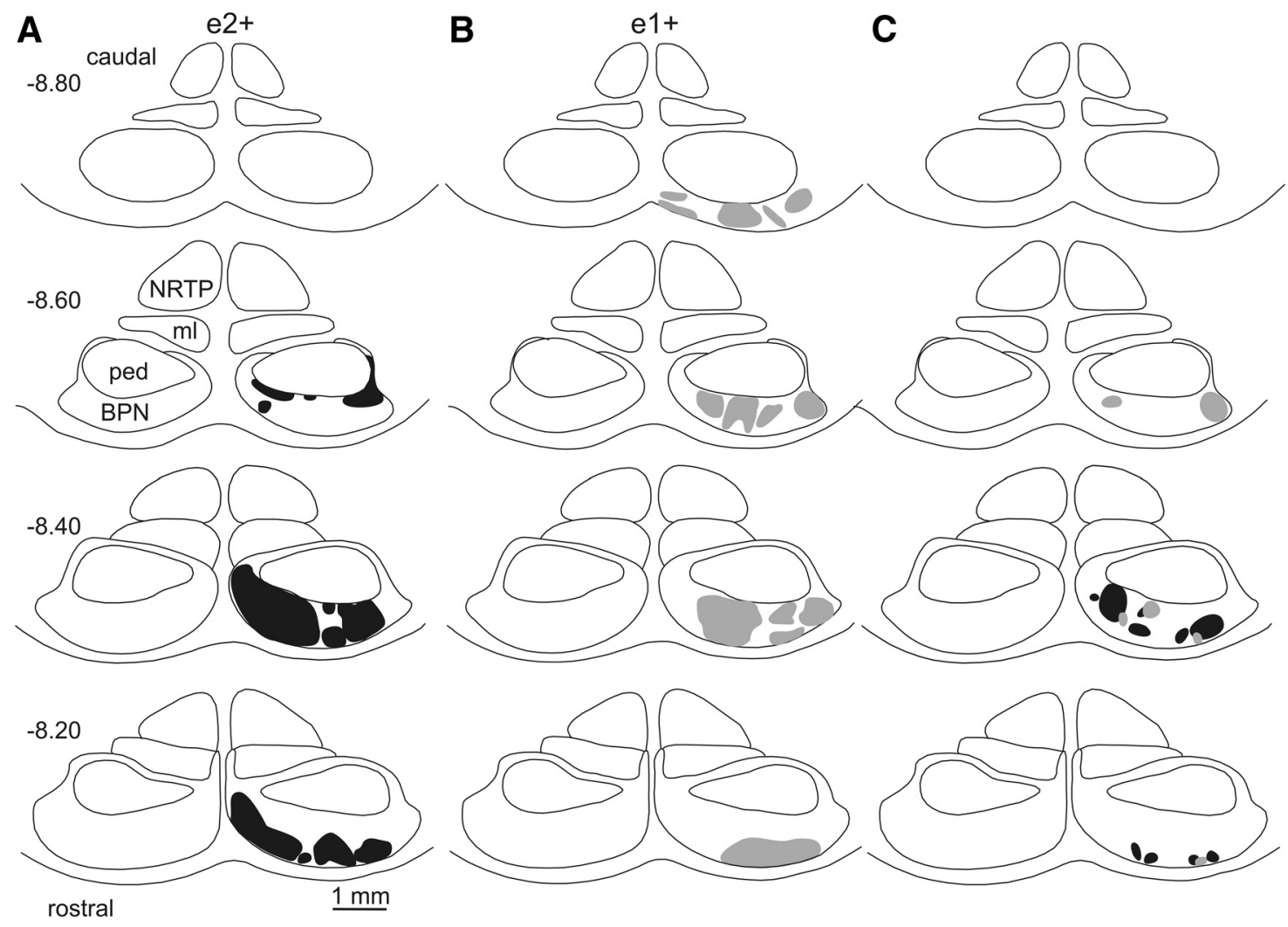

Figure 7. Pooled cases of pontocerebellar projections associated with different zebrin bands in the C1 zone in CP. $A$, Standard transverse maps of the pons (AP levels -8.2 to -8.8 ) showing the total area in BPN occupied by cell labeling (black shading) for all injection sites centered on zebrin band e $2+(n=4)$. B Same as $\boldsymbol{A}$ but for all injections sites centered on zebrin band e1+ $(n=4$, gray shading). C, Core areas occupied by cell labeling in at least 3 cases: e2 + (black) and e1+ (gray). BPN, Basilar pontine nuclei; c, caudal; l, lateral; $\mathrm{m}$, medial; ml, medial lemniscus; ped, cerebral peduncle; NRTP, nucleus reticularis tegmenti pontis; $r$, rostral.

tended to the olivonuclear projection, represented by the distribution of retrogradely labeled cells in vDAO. This implies a close correspondence between olivo-cortico-nuclear and olivonuclear projections at the microcircuit level of resolution.

\section{Discussion}

In the present study, we examined the microarchitecture of the $\mathrm{C} 1$ zone in $\mathrm{CP}$ of the rat cerebellum and provide evidence for microcircuits defined by specific olivocerebellar and corticonuclear connections associated with individual zebrin bands (Fig. 9). We also found that this connectivity extends to olivonuclear and pontocerebellar projections and that there is a correlation between microarchitecture and somatotopical representation of different parts of the ipsilateral hindpaw within the $\mathrm{C} 1$ zone. Our results therefore represent the most comprehensive description to date of the fine grain anatomical circuitry underlying information processing within an individual cerebellar zone.

\section{One-map hypothesis}

The one-map hypothesis postulates that, during embryogenesis, MFs and CFs use longitudinally oriented bands of PC clusters as a scaffold to organize their topography (Apps and Hawkes, 2009). This leads to two predictions: (1) at the microcircuit level, there is an alignment between MF and CF terminations, and (2) that these terminations respect PC molecular marker boundaries. The results strongly support this hypothesis because they satisfy both of these predictions. The present study also extends the one-map concept by showing that this microcircuit connectivity is conserved in the pattern of PC outputs to the cerebellar nuclei.

\section{Limitations of the present study}

The electrophysiological techniques we used to map somatotopical organization is unlikely to represent a true microzonal level of organization (Garwicz et al., 1998 for further discussion). However, injection site size $(\sim 0.1 \mathrm{~mm})$ meant that the anatomical mapping was judged to be at this level. An assumption for paired injection sites was that the effective region of uptake was similar for retrograde and anterograde transport of tracer. Two lines of evidence support this assumption: (1) quantitative analysis of paired injection sites indicated that mediolateral disparity between them was usually smaller than $0.1 \mathrm{~mm}$ and (2) paired injections restricted to different zebrin bands resulted in corresponding topographical differences for both anterograde and retrograde labeling.

An additional consideration is that our results were limited to a comparison of PC inputs and outputs with the expression of zebrin II. Although zebrin II is the most comprehensively studied cerebellar molecular marker, there are many others; some reveal similar band-like patterns (e.g., phospholipase C $\beta 3$; Sarna et al., 2006) and others have a spatial distribution that has been described as "patchy" (e.g., heat shock protein 25; Armstrong and Hawkes, 2000). It is an open question whether zebrin II represents a more fundamental marker of PC function than others. However, it does provide a well established frame of reference for identifying specific cerebellar cortical regions, allowing comparison of physiological function across experiments.

Another consideration is that our data were confined to study of the $\mathrm{C} 1$ zone in CP. Similar microscale investigation of other 

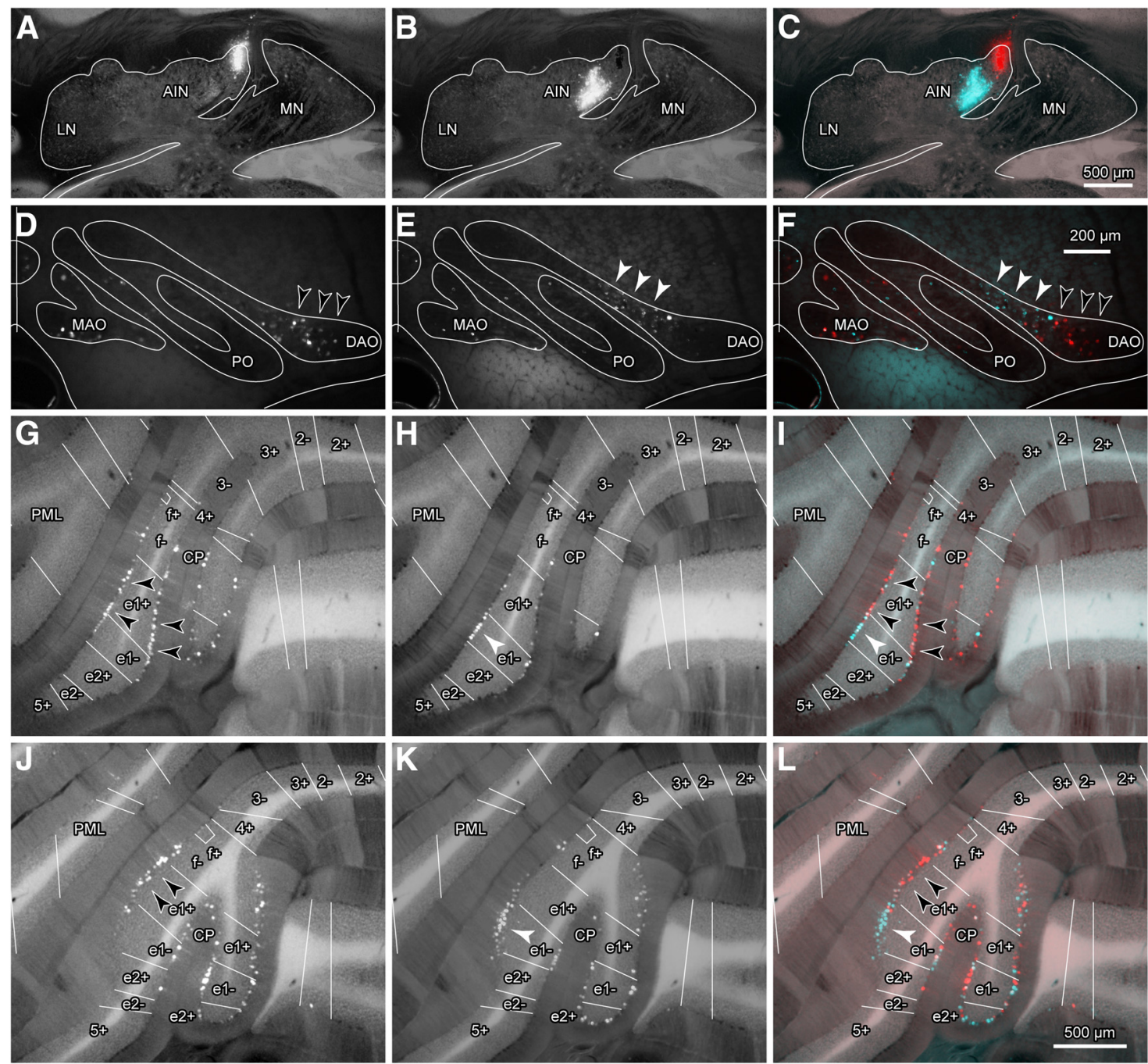

Figure 8. Retrograde tracer injections into the cerebellar nuclei. $\boldsymbol{A}$, Example of red Retrobead injection site in interpositus nucleus. $\boldsymbol{B}$, Example of green Retrobead injection site in interpositus nucleus in the same section as $\boldsymbol{A}$. C, Same as $\boldsymbol{A}$ and $\boldsymbol{B}$ but with fluorescent images of red and green Retrobead injection sites superimposed with dim bright-field illumination to visualize DAB-stained zebrin bands and contours of cortical and nuclear structures. Scale bar in $\boldsymbol{C a l s o}$ applies to $\boldsymbol{A}$ and $\boldsymbol{B}$. $\boldsymbol{D}-\boldsymbol{F}$, Retrogradely labeled cells in the inferior olive. $\boldsymbol{D}, \boldsymbol{E}$, Cells labeled with red Retrobeads (black arrowheads) and green Retrobeads (white arrowheads), respectively. $\boldsymbol{F}$, Same as $\boldsymbol{D}$ and $\boldsymbol{E}$ but with fluorescent images of red and green Retrobeads cell labeling superimposed on the same bright-field view. Scale bar in $\boldsymbol{F}$ also applies to $\boldsymbol{D}$ and $\boldsymbol{E}$. G- $\boldsymbol{L}$, Retrogradely labeled PCs in CP. G, J, PCs labeled with red Retrobeads (black arrowheads indicate location of highest density of cell labeling). $\boldsymbol{H}, \boldsymbol{K}$, PCs labeled with green Retrobeads (white arrowheads indicate location of highest density of cell labeling). $\boldsymbol{I}, \boldsymbol{L}$, Same as $\boldsymbol{G}, \boldsymbol{H}, \boldsymbol{J}, \boldsymbol{K}$ but with fluorescent images of red and green Retrobeads cell labeling superimposed on the same bright-field view to visualize DAB-stained zebrin bands. Scale bar in $\boldsymbol{L}$ also applies to $\boldsymbol{G}-\boldsymbol{K}$. All images were obtained from the same experiment. Zebrin bands are indicated by white lines in $\mathbf{G}-\mathbf{L}$. LN, lateral nucleus; MA0, medial accessory olive; MN, medial nucleus; PML, paramedian lobule; P0, principal olive.

cerebellar regions is required before it can be safely concluded that the close correspondence we found between inputs/outputs and $\mathrm{PC}$ phenotype is a general rule. The precise connectivity that we found may be necessary for limb control, whereas cerebellar regions involved in other functions (e.g., balance) may require a different pattern of connectivity. An additional issue is that MFs target granule cells and influence PCs indirectly through the granule cell-parallel fiber pathway. Parallel fibers extend for many millimeters in the long axis of individual folia (Harvey and Napper, 1991; Pichitpornchai et al., 1994) and therefore can contact many PCs located in multiple zebrin bands. This raises the possibility that PCs are influenced mainly by nonlocal MFs (Garwicz and Andersson, 1992; Barmack and Yakhnitsa, 2008). However, other studies indicate that the ascending axons of granule cells make powerful direct connections with PCs, suggesting they are influenced mainly by local MF inputs (Bower and Woolston, 1983; Cohen and Yarom, 1998). To resolve these and the other issues raised above will require a combination of high-resolution anatomical, molecular, and single-unit mapping techniques. We believe that the present results provide a useful foundation for such studies.

\section{Olive maps}

In agreement with previous work (Buisseret-Delmas, 1988; Apps, 1990; Garwicz et al., 1996), we found that olive topography is best described by a 2D map made up of rostrocaudally oriented columns of olive cells. However, we extend this concept to a microcircuit level of resolution and show a close correspondence between segments of olivary columns and individual zebrin bands of PCs. Injections of anterograde tracer into different levels of lumbosacral cord result in an orderly pattern of rostrocaudally oriented columns of terminal labeling within DAO (Armstrong et al., 1982; Matsushita et al., 1992). Together with the present findings, this strongly suggests that, at a microcircuit level, the cerebellar cortex in $\mathrm{CP}$ receives a specific pattern of spino-olivary input relayed via a column of olive cells within DAO. 


\section{Pontine maps}

Previous studies of cerebropontine projections have found that small regions of cerebral cortex provide terminal fields distributed into multiple clusters within $\mathrm{BPN}$ that aggregate to form concentric lamellae and receive inputs from different cerebral cortical regions (Brodal and Walberg, 1977; Brodal, 1987; Leergaard et al., 1995; Brodal and Bjaalie, 1997). A lamellar-like organization has also been reported for pontocerebellar projections (Nikundiwe et al., 1994). In general, these studies support the view that somatotopical relationships are preserved within the cerebropontine projection and that the fractured somatotopical map characteristic of cerebellar cortical granular layer receptive fields (Shambes et al., 1978) arises mainly from MF axon collateralization. In contrast, others have emphasized the importance of the initial cerebropontine stage in generating the fragmentation of the cerebellar cortical body map (Schwarz and Thier, 1999, 2000; Schwarz and Möck, 2001).

These competing viewpoints can be resolved by suggesting a two-step process in the transformation from an ordered cerebral map to a fractured cerebellar map. In the present study, when pontine cell labeling was pooled (thereby representing a significant fraction of the whole mediolateral width of the $\mathrm{C} 1$ zone in $\mathrm{CP}$ ), most of the territory within BPN was occupied by labeled cells, forming a lamellar-like distribution. However, when cases were considered individually in relation to specific zebrin bands (and therefore at the level of individual microcircuits within the broader $\mathrm{C} 1$ zone), the cell labeling generally formed multiple clusters within BPN. In double tracer studies in which the two injection sites were centered on different zebrin bands, the clusters of pontine cell labeling were mainly non-overlapping. Therefore, at the level of a whole cerebellar zone, a lamellar organization is present within BPN, but the spatial distribution fragments into multiple cell clusters at a microcircuit level of resolution.

At a macroscale, MF terminations usually occur bilaterally within the cerebellar cortex with a tendency to form multiple, longitudinally oriented stripes, resulting in a complex relationship with zebrin bands (Gravel and Hawkes, 1990; Ruigrok et al., 1995; Wu et al., 1999; Serapide et al., 2001; Voogd et al., 2003; Quy et al., 2011). This would appear to be at odds with our results. However, at a microscale, the pattern of termination of single MFs axons is consistent with our findings. For example, a study of projections from the dorsal column nuclei found that the distribution of MF terminals arising from a single stem axon were often closely related to an individual zebrin band (Quy et al., 2011).

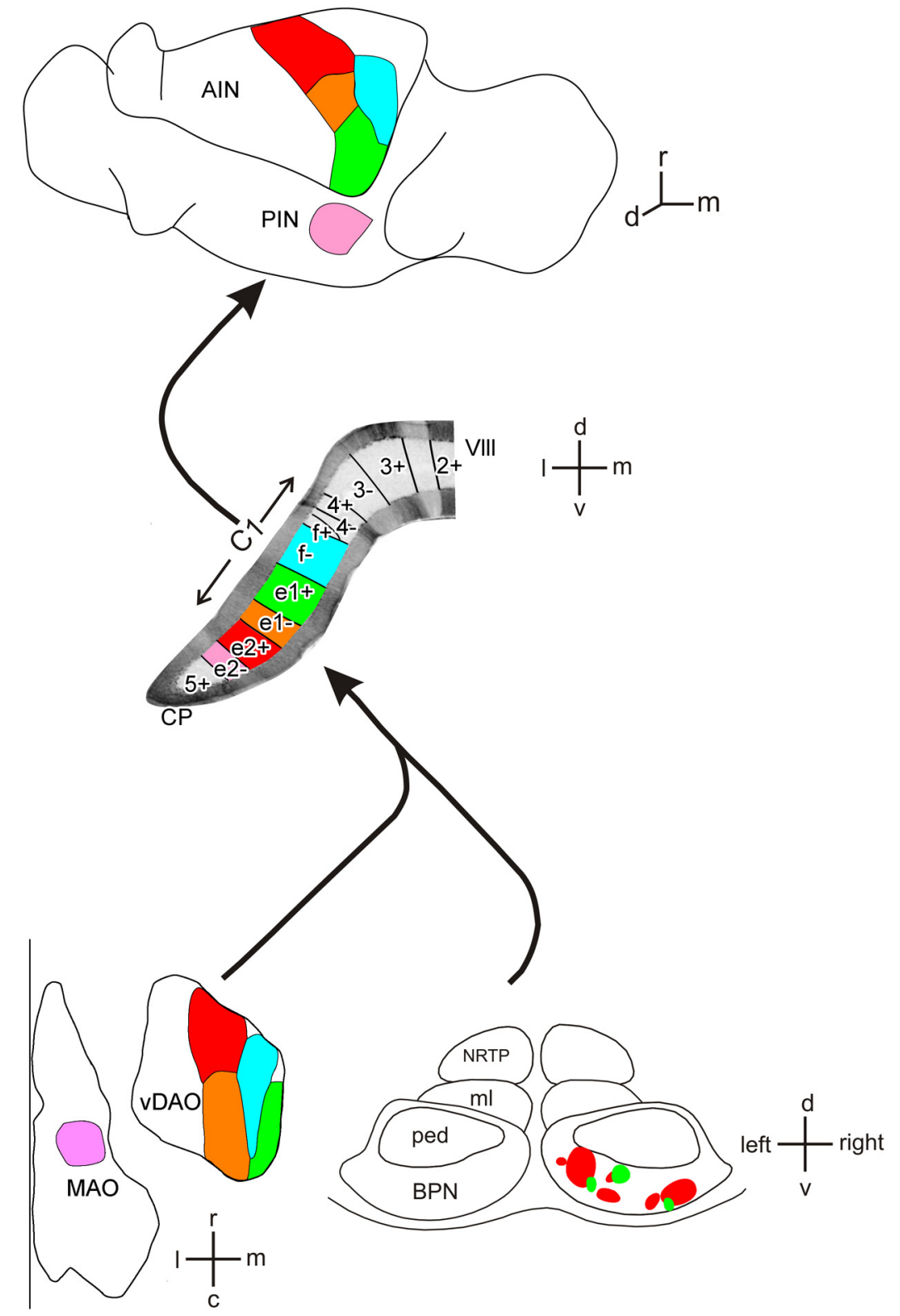

Figure 9. Summary diagram of olivocerebellar, corticonuclear, and pontocerebellar microcircuits within the CP of the rat cerebellum as deduced in the present study. Top, Horizontal view of the left cerebellar nuclei. Middle, Transverse view of the left cerebellar lobule VIII (vermis and (P) with zebrin bands. Approximate mediolateral width of $\mathrm{C} 1$ zone in CP is shown. Bottom, Horizontal maps of the right inferior olive (principal olive not shown) and a transverse view of the pons. Matching colors show for individual zebrin bands the sites of origin of CFs in the contralateral inferior olive, the source of MFs from the contralateral BPN and ( accessory olive; ml, medial lemniscus; ped, cerebral peduncle; NRTP, nucleus reticularis tegmenti pontis; PIN, posterior interpositus nucleus; r, rostral; v, ventral; VIII, lobule 8.

\section{Cerebellar nuclear maps}

By demonstrating that a fine grain topography exists, the present study significantly extends earlier work on corticonuclear projections from CP to medial AIN (Courville et al., 1973; Bishop et al., 1979; Dietrichs and Walberg, 1979; Umetani and Tabuchi, 1988; Trott et al., 1998). Different microzones within the C1 zone in CP correspond to individual zebrin bands and map onto a $2 \mathrm{D}$ pattern of territories within medial AIN. In the rat, individual PC axons form highly localized terminations within AIN (Sugihara et al., 2009; Sugihara, 2011), which would be expected if a detailed topography is present. It should be emphasized, however, that the precise corticonuclear relationship found in the present study 
may not hold true for other nuclear territories, particularly the medial nucleus, in which PC terminal arbors are broader than in AIN (Sugihara et al., 2009).

\section{Concluding comments}

We provide evidence in rat for a microcircuit organization within the $\mathrm{C} 1$ zone in $\mathrm{CP}$ where a close topographical alignment occurs among MF, CF, PC phenotype, and corticonuclear projections. Such a relationship is predicted by the one-map hypothesis and is consistent with the general notion that a small MF patch is spatially congruent with a CF microzone and, together, these inputs respect the boundaries of zebrin bands (Apps and Hawkes, 2009). The functional significance of this elaborate organization remains to be determined. However, the results raise the possibility that private lines of communication are conserved from cerebellar input to output, although this does not exclude "cross talk" that could occur at any/all stages of signal transmission. It may also be relevant that information processing in the cerebellar cortex may not be as uniform as generally assumed. For example, some differences in physiology between zebrin-positive and zebrin-negative bands have been found (Wadiche and Jahr, 2005; Gao et al., 2006; Mostofi et al., 2010; Paukert et al., 2010; but see Pakan et al., 2011 Graham and Wylie, 2012). At least theoretically, the present results therefore provide the substrate to enable spatial differences in information processing at a microcircuit level of cerebellar organization.

\section{References}

Apps R (1990) Columnar organisation of the inferior olive projection to the posterior lobe of the rat cerebellum. J Comp Neurol 302:236-254. CrossRef Medline

Apps R, Garwicz M (2005) Anatomical and physiological foundations of cerebellar information processing. Nat Rev Neurosci 6:297-311. CrossRef Medline

Apps R, Hawkes R (2009) Cerebellar cortical organization: a one-map hypothesis. Nat Rev Neurosci 10:670-681. CrossRef Medline

Armstrong CL, Hawkes R (2000) Pattern formation in the cerebellar cortex. Biochem Cell Biol 78:551-562. CrossRef Medline

Armstrong DM, Campbell NC, Edgley SA (1982) Investigations of the olivo-cerebellar and spino-olivary pathways. In: The cerebellum-new vistas (Palay SL, Chan-Palay V, eds), pp 195-232. Berlin: Springer.

Atkins MJ, Apps R (1997) Somatotopical organisation within the climbing fibre projection to the paramedian lobule and copula pyramidis of the rat cerebellum. J Comp Neurol 389:249-263. CrossRef Medline

Barmack NH, Yakhnitsa V (2008) Distribution of granule cells projecting to focal Purkinje cells in mouse uvula-nodulus. Neuroscience 156:216-221. CrossRef Medline

Bishop GA, McCrea RA, Lighthall JW, Kitai ST (1979) An HRP and autoradiographic study of the projection from the cerebellar cortex to the nucleus interpositus anterior and nucleus interpositus posterior of the cat. J Comp Neurol 185:735-756. CrossRef Medline

Bower JM, Woolston DC (1983) Congruence of spatial organization of tactile projections to granule cell and Purkinje cell layers of cerebellar hemispheres of the albino rat: vertical organization of cerebellar cortex. J Neurophysiol 49:745-766. Medline

Brochu G, Maler L, Hawkes R (1990) Zebrin II: a polypeptide antigen expressed selectively by Purkinje cells reveals compartments in rat and fish cerebellum. J Comp Neurol 291:538-552. CrossRef Medline

Brodal P (1987) Organization of cerebropontocerebellar connections as studied with anterograde and retrograde transport of HRP-WGA in the rat. In: New concepts in cerebellar neurobiology (King JS, ed), pp 151182. New York: Alan R. Liss.

Brodal P, Bjaalie JG (1997) Salient anatomic features of the cortico-pontocerebellar pathway. Prog Brain Res 114:227-249. CrossRef Medline

Brodal P, Walberg F (1977) The pontine projection to the cerebellar anterior lobe. An experimental study in the cat with retrograde transport of horseradish peroxidase. Exp Brain Res 29:233-248. Medline

Buisseret-Delmas C (1988) Sagittal organization of the olivocerebellonu- clear pathway in the rat. I. Connections with the nucleus fastigii and the nucleus vestibularis lateralis. Neurosci Res 5:475-493. CrossRef Medline

Buisseret-Delmas C, Angaut P (1993) The cerebellar olivo-corticonuclear connections in the rat. Prog Neurobiol 40:63-87. CrossRef Medline

Buisseret-Delmas C, Yatim N, Buisseret P, Angaut P (1993) The X zone and CX subzone of the cerebellum in the rat. Neurosci Res 16:195-207. CrossRef Medline

Cicirata F, Serapide MF, Parenti R, Pantò MR, Zappalà A, Nicotra A, Cicero D (2005) The basilar pontine nuclei and the nucleus reticularis tegmenti pontis subserve distinct cerebrocerebellar pathways. Prog Brain Res 148: 259-282. CrossRef Medline

Cohen D, Yarom Y (1998) Patches of synchronized activity in the cerebellar cortex evoked by mossy-fiber stimulation: questioning the role of parallel fibers. Proc Natl Acad Sci U S A 95:15032-15036. CrossRef Medline

Courville J, Diakiw N, Brodal A (1973) Cerebellar corticonuclear projection in the cat. The paramedian lobule. An experimental study with silver methods. Brain Res 50:25-45. CrossRef Medline

Dietrichs E, Walberg F (1979) The cerebellar corticonuclear and nucleocortical projections in the cat as studied with anterograde and retrograde transport of horseradish peroxidase. I. The paramedian lobule. Anat Embryol (Berl) 158:13-39. CrossRef Medline

Fujita H, Morita N, Furuichi T, Sugihara I (2012) Clustered fine compartmentalization of the mouse embryonic cerebellar cortex and its rearrangement into the postnatal striped configuration. J Neurosci 32:15688-15703. CrossRef Medline

Gao W, Chen G, Reinert KC, Ebner TJ (2006) Cerebellar cortical molecular layer inhibition is organized in parasagittal zones. J Neurosci 26:83778387. CrossRef Medline

Garwicz M, Andersson G (1992) Spread of synaptic activity along parallel fibres in cat cerebellar anterior lobe. Exp Brain Res 88:615-622. Medline

Garwicz M, Apps R, Trott JR (1996) Micro-organization of olivocerebellar and corticonuclear connections of the paravermal cerebellum in the cat. Eur J Neurosci 8:2726-2738. CrossRef Medline

Garwicz M, Ekerot CF, Jörntell H (1998) Organizational principles of cerebellar neuronal circuitry. News Physiol Sci 13:26-32. Medline

Graham DJ, Wylie DR (2012) Zebrin-immunopositive and -immunonegative stripe pairs represent functional units in the pigeon vestibulocerebellum. J Neurosci 32:12769-12779. CrossRef Medline

Gravel C, Hawkes R (1990) Parasagittal organization of the rat cerebellar cortex: direct comparison of Purkinje cell compartments and the organization of the spinocerebellar projection. J Comp Neurol 291:79-102. CrossRef Medline

Harvey RJ, Napper RM (1991) Quantitative studies on the mammalian cerebellum. Prog Neurobiol 36:437-463. CrossRef Medline

Herrero L, Pardoe J, Apps R (2002) Pontine and lateral reticular projections to the $\mathrm{cl}$ zone in lobulus simplex and paramedian lobule of the rat cerebellar cortex. Cerebellum 1:185-199. CrossRef Medline

Larsell O (1952) The morphogenesis and adult pattern of the lobules and fissures of the cerebellum of the white rat. J Comp Neurol 97:281-356. CrossRef Medline

Leergaard TB, Lakke EA, Bjaalie JG (1995) Topographical organization in the early postnatal corticopontine projection: a carbocyanine dye and 3-D computer reconstruction study in the rat. J Comp Neurol 361:77-94. CrossRef Medline

Matsushita M, Yaginuma H, Tanami T (1992) Somatotopic termination of the spino-olivary fibers in the cat, studied with the wheat germ agglutininhorseradish peroxidase technique. Exp Brain Res 89:397-407. Medline

Mostofi A, Holtzman T, Grout AS, Yeo CH, Edgley SA (2010) Electrophysiological localization of eyeblink-related microzones in rabbit cerebellar cortex. J Neurosci 30:8920-8934. CrossRef Medline

Nikundiwe AM, Bjaalie JG, Brodal P (1994) Lamellar organization of pontocerebellar neuronal populations. A multi-tracer and 3-D computer reconstruction study in the cat. Eur J Neurosci 6:173-186. CrossRef Medline

Pakan JM, Graham DJ, Gutiérrez-Ibáñez C, Wylie DR (2011) Organization of the cerebellum: correlating zebrin immunochemistry with optic flow zones in the pigeon flocculus. Vis Neurosci 28:163-174. CrossRef Medline

Paukert M, Huang YH, Tanaka K, Rothstein JD, Bergles DE (2010) Zones of enhanced glutamate release from climbing fibers in the mammalian cerebellum. J Neurosci 30:7290-7299. CrossRef Medline 
Paxinos G, Watson C (2007) The rat brain in stereotaxic coordinates. Sydney: Academic.

Pichitpornchai C, Rawson JA, Rees S (1994) Morphology of parallel fibres in the cerebellar cortex of the rat: an experimental light and electron microscopic study with biocytin. J Comp Neurol 342:206-220. CrossRef Medline

Pijpers A, Apps R, Pardoe J, Voogd J, Ruigrok TJ (2006) Precise spatial relationships between mossy fibers and climbing fibers in rat cerebellar cortical zones. J Neurosci 26:12067-12080. CrossRef Medline

Pijpers A, Winkelman BH, Bronsing R, Ruigrok TJ (2008) Selective impairment of the cerebellar $\mathrm{C} 1$ module involved in rat hind limb control reduces step-dependent modulation of cutaneous reflexes. J Neurosci 28: 2179-2189. CrossRef Medline

Quy PN, Fujita H, Sakamoto Y, Na J, Sugihara I (2011) Projection patterns of single mossy fiber axons originating from the dorsal column nuclei mapped on the aldolase C compartments in the rat cerebellar cortex. J Comp Neurol 519:874-899. CrossRef Medline

Ramnani N (2006) The primate cortico-cerebellar system: anatomy and function. Nat Rev Neurosci 7:511-522. CrossRef Medline

Ruigrok TJ (2011) Ins and outs of cerebellar modules. Cerebellum 10:464474. CrossRef Medline

Ruigrok TJ, Cella F, Voogd J (1995) Connections of the lateral reticular nucleus to the lateral vestibular nucleus in the rat. An anterograde tracing study with Phaseolus vulgaris leucoagglutinin. Eur J Neurosci 7:14101413. CrossRef Medline

Sarna JR, Marzban H, Watanabe M, Hawkes R (2006) Complementary stripes of phospholipase Cbeta3 and Cbeta4 expression by Purkinje cell subsets in the mouse cerebellum. J Comp Neurol 496:303-313. CrossRef Medline

Schwarz C, Möck M (2001) Spatial arrangement of cerebro-pontine terminals. J Comp Neurol 435:418-432. CrossRef Medline

Schwarz C, Thier P (1999) Binding of signals relevant for action: towards a hypothesis of the functional role of the pontine nuclei. Trends Neurosci 22:443-451. CrossRef Medline

Schwarz C, Thier P (2000) Reply. Trends Neurosci 23:152-153. CrossRef Medline

Serapide MF, Pantó MR, Parenti R, Zappalá A, Cicirata F (2001) Multiple zonal projections of the basilar pontine nuclei to the cerebellar cortex of the rat. J Comp Neurol 430:471-484. CrossRef Medline

Shambes GM, Gibson JM, Welker W (1978) Fractured somatotopy in granule cell tactile areas of rat cerebellar hemispheres revealed by micromapping. Brain Behav Evol 15:94-140. CrossRef Medline
Sugihara I (2011) Compartmentalization of the deep cerebellar nuclei based on afferent projections and aldolase $\mathrm{C}$ expression. Cerebellum 10:449-463. CrossRef Medline

Sugihara I, Fujita H (2013) Peri- and postnatal development of cerebellar compartments in the mouse. Cerebellum 12:325-327. CrossRef Medline

Sugihara I, Shinoda Y (2004) Molecular, topographic, and functional organization of the cerebellar cortex: a study with combined aldolase $\mathrm{C}$ and olivocerebellar labeling. J Neurosci 24:8771-8785. CrossRef Medline

Sugihara I, Shinoda Y (2007) Molecular, topographic, and functional organization of the cerebellar nuclei: analysis by three-dimensional mapping of the olivonuclear projection and aldolase C labeling. J Neurosci 27: 9696-9710. CrossRef Medline

Sugihara I, Fujita H, Na J, Quy PN, Li BY, Ikeda D (2009) Projection of reconstructed single Purkinje cell axons in relation to the cortical and nuclear aldolase $\mathrm{C}$ compartments of the rat cerebellum. J Comp Neurol 512:282-304. CrossRef Medline

Trott JR, Apps R, Armstrong DM (1998) Zonal organization of corticonuclear and nucleo-cortical projections of the paramedian lobule of the cat cerebellum. 1. The C1 zone. Exp Brain Res 118:298-315. CrossRef Medline

Umetani T, Tabuchi T (1988) Topographic organization of the corticonuclear and corticovestibular projections from the pyramis and copula pyramidis in the albino rat. An autoradiographic orthograde tracing study. Brain Behav Evol 32:160-168. CrossRef Medline

Voogd J (2004) Cerebellum and precerebellar nuclei. In: The human nervous system (Paxinos G, Mai JK, eds), pp 322-392. Amsterdam: Elsevier.

Voogd J, Bigaré F, Gerrits NM, Marani E (1981) Structure and fiber connections of the cerebellum. Prog Clin Biol Res 59A:259-268. Medline

Voogd J, Pardoe J, Ruigrok TJ, Apps R (2003) The distribution of climbing and mossy fiber collateral branches from the copula pyramidis and the paramedian lobule: congruence of climbing fiber cortical zones and the pattern of zebrin banding within the rat cerebellum. J Neurosci 23:46454656. Medline

Wadiche JI, Jahr CE (2005) Patterned expression of Purkinje cell glutamate transporters controls synaptic plasticity. Nat Neurosci 8:1329-1334. CrossRef Medline

Wu HS, Sugihara I, Shinoda Y (1999) Projection patterns of single mossy fibers originating from the lateral reticular nucleus in the rat cerebellar cortex and nuclei. J Comp Neurol 411:97-118. CrossRef Medline

Yeo CH, Hesslow G (1998) Cerebellum and conditioned reflexes. Trends Cogn Sci 2:322-330. CrossRef Medline 